\title{
Biochars in Iron Ores Sintering Process: Effect on Sinter Quality and Emission
}

\author{
Marian Niesler ${ }^{1, * \mathbb{D}}$, Janusz Stecko ${ }^{1}$, Sławomir Stelmach ${ }^{2}$ and Anna Kwiecińska-Mydlak ${ }^{2}$ (D) \\ 1 Łukasiewicz Research Network-Institute for Ferrous Metallurgy, K. Miarki 12-14 St, 44-100 Gliwice, Poland; \\ Janusz.Stecko@imz.pl \\ 2 Institute for Chemical Processing of Coal, Zamkowa 1 St, 41-803 Zabrze, Poland; sstelmach@ichpw.pl (S.S.); \\ akwiecinska@ichpw.pl (A.K.-M.) \\ * Correspondence: Marian.Niesler@imz.pl
}

check for updates

Citation: Niesler, M.; Stecko, J.; Stelmach, S.; Kwiecińska-Mydlak, A. Biochars in Iron Ores Sintering Process: Effect on Sinter Quality and Emission. Energies 2021, 14, 3749. https://doi.org/10.3390/ en14133749

Academic Editor: Elisabetta Arato

Received: 28 April 2021

Accepted: 21 June 2021

Published: 22 June 2021

Publisher's Note: MDPI stays neutral with regard to jurisdictional claims in published maps and institutional affiliations.

Copyright: (C) 2021 by the authors. Licensee MDPI, Basel, Switzerland. This article is an open access article distributed under the terms and conditions of the Creative Commons Attribution (CC BY) license (https:/ / creativecommons.org/licenses/by/ $4.0 /)$.

\begin{abstract}
The article presents results of the research on the use of chars produced during pyrolysis of residual biomass as a substitutional fuel in the iron ore sintering process. Such an approach allows to implement circular economy and industrial symbiosis to the iron and steel branches. The effect of the substitution of conventional coke breeze fuel used in sintering on final sinter quality and emission was examined. With regard to productivity, fuel consumption, and properties of the sinter it was shown that the share of tested biochars in fuel may be kept at 10, and up to $30 \mathrm{wt} . \%$, depending on the biochar type. It was observed that with the use of the biochars, the content of iron oxide in the sinter decreased, which was advantageous. Moreover, the sinter obtained in the presence of biochars was characterized with better strength and abrasion than the sinter obtained with coke breeze-based fuel, improving the final product quality. The presence of biochar influenced the raw exhaust gas composition and resulted in a slight increase of organic and inorganic carbon compounds content, while the amount of sulfur oxides was noticeably decreased. It was concluded that the biochars may be applied in the sintering process at established share in the fuel stream.
\end{abstract}

Keywords: pyrolysis; residual biomass; biochar; substitutional fuel; environmental effect

\section{Introduction}

Nowadays, the concept of circular economy has become the fundamental economy model of developed regions, and it is spread and intensively implemented all over the world [1,2]. One of its most important aspects is to increase the rate of reuse, recycling, and recovery of resources, which allows for the optimum utilization of available raw materials, residues, and wastes and results in energy saving and reduction of environmental emissions, especially greenhouse gases (GHGs) to the atmosphere [3]. Due to this fact, actions related with the circular economy approach are also implemented to metallurgical processes, which are regarded as some of the most energy-demanding and materialsconsuming industrial branches. Early studies on the circular economy in iron and steel enterprises discuss the evaluation of cleaner production, further supplemented with the concept of "efficiency" introduced to evaluate the level of the circular economy. These include both overall resource efficiency and iron resource efficiency [4].

There are two main routes of steel production of industrial importance currently used worldwide. A total of $70 \%$ of the world steel is produced by the route of blast furnace (BF), in which iron ore is reduced to pig iron, followed by pig iron conversion into steel in a basic oxygen furnace (BOF). Inputs of this route are mainly iron ore, coal, limestone, and, to a much lower extent, steel scrap. The second route, within which $30 \%$ of the world's steel is produced, is based on the electric arc furnace (EAF), which involves scrap steel as feedstock as well as electricity as energy source [5]. Additionally, in this route, carbon sources are of great importance, as, in modern electric arc furnaces, the share of energy input from fossil fuels such as natural gas and coal is over $40 \%$ of the total energy input. 
Solid carbon sources, such as coal, petrol, coke, etc., are used in the EAF as slag foaming agents [6].

Significant efforts and commitments are undertaken within both European and worldwide activities in steel industry by introducing innovative actions on high-performance products and increasing process efficiency by also reducing its environmental impacts [5]. For example, the use of residual coke structural fractions in the blast furnace (BF) process is commonly implemented in the sector. In the case of the iron ore sintering process, there are preliminary actions related with the possibility of recovery of iron from zinced blast furnace or basic oxygen furnace slurries or their reuse in other industrial branches. Other actions are focused on the use of novel fuels suitable to substitute conventional fossil fuels currently used in iron ore sintering processes [7-13]. The latter is in agreement with the creation of industrial symbiosis (IS), targeted on the development of synergy routes between different sectors. Through the IS concept implementation, byproducts, residues, or wastes from one sector (e.g., agriculture, biomass processing) may become valuable feedstocks to other sectors (e.g., iron and steel production) [5].

The sintering process is an important raw material preparation step for the production of hot metal in blast furnaces [14]. It is a thermal agglomeration process $\left(1300-1480^{\circ} \mathrm{C}\right)$ of a mixture of iron ore mineral fines $(0.5-8.0 \mathrm{~mm})$ and other materials, such as byproducts of the iron and steelmaking industry, fluxes, slag-forming elements, and fossil fuels (coke breeze, i.e., the fraction of coke of the smallest grain size below $12 \mathrm{~mm}$ ). The objective of the process is to obtain a load $(12-35 \mathrm{~mm})$ with the suitable physical-chemical and mechanical properties, which can be further processed in a blast furnace to produce pig iron [15]. Sintering is the most economic and widely used agglomeration process to prepare iron ore fines for blast furnace use. Compared with pellets, production of sinter is cheaper, and compared with lump ore, fluxed sinter is often more reducible with better softening characteristics [14].

Sintering is an energy-intensive (1.4-2.6 MWh/t [16]) and complex process, in which a number of parameters have to be taken into account [17]. The basic fuel for the iron ore sintering process is coke breeze (CB), the use of which can be supported by substitutional fuels, e.g., anthracite [18]. However, the number of actions dedicated to substitution of conventional fuels by other ones, preferably of renewable or bio (or generally green) features, are taken. Among them, chars derived from residual biomass, formed during pyrolysis of selected feedstocks (biodegradable residues or wastes), are of high interest. Pyrolysis is a thermal process during which organic substances, at the absence of oxygen, are thermochemically processed to gaseous, liquid, and solid products. Hence, in the case of residues, their transformation to useable materials, e.g., a fuel for metallurgical process, takes place, and thus such the processing of residues fully agrees with the circular economy concept.

Residual biomass, especially from the agricultural sector, is regarded as a valuable, renewable energy source. European agriculture annually generates $442,000 \mathrm{Gg}$ of residues (dry matter), which correspond to $46 \%$ of overall agriculture biomass production. Most of the residues are generated during production of cereals $(74 \%$ of total agricultural residue production) and oil-bearing crops (17\%). The main producers of residual biomass in Europe are France $(83,600 \mathrm{Gg}$ /year, dry matter), Germany (59,200 Gg/year, dry matter), and Poland (45,500 Gg/year, dry matter). In the case of the use of biomass for energetic purposes, agricultural biomass in Europe represents 27\% of the overall biomass supply [19]. It is estimated that Polish resources of biomass, which could be used as a renewable energy source, could deliver $835 \mathrm{PJ} /$ year (overall biomass potential), while nowadays they deliver $263 \mathrm{PJ} /$ year [20]. The unfavorable features of biomass, such as poor grinding capability, low energy density, high moisture content, irregular structure (shape and size), and non-uniform composition, usually limit its direct use as a fuel, especially in metallurgical processes.

It has been shown that the direct utilization of biomass for replacement of coal in iron and steel processes is affected by improper storage and unavailability of technological 
developments required for biomass fuel. Additionally, high moisture content lowering the biomass heating value is also disadvantageous, while it can be improved by proper storage and pretreatment section. Conversion methods should also be considered in order to enable the use of any type of biomass [17]. There are also some other disadvantages related with the composition and properties of biomass, which include high oxygen content in biomass, presence of water-soluble fractions, alkaline, and halogen elements, and some hazardous trace elements, also connected with highly variable composition and properties of biomass. Another issue is the indefinite availability of sustainable biomass resources [21]. In literature, there is research focused on technological, economic, and environmental analysis of substitution of coke breeze (CB) with raw biomass in the iron ore sintering process. The impact of the biomass share in sintering mixture on process parameters and final sinter quality has been investigated. It was found that the addition of biomass up to $10 \mathrm{wt} . \%$ in fuel (as the substitute of CB) resulted in the decrease of permeability, and thus in the decrease of the process capacity. Moreover, the increase of overall fuel consumption (coke breeze and biomass) was observed, which adversely affected the economy of the process. The increase of $\mathrm{CO}_{2}, \mathrm{CO}$, and $\mathrm{NO}_{\mathrm{x}}$ in exhaust gases was also observed. Hence, it was concluded that the use of raw biomass in the sintering process was inefficient [22-24].

One of the methods enabling the improvement of biomass properties and, thus, increasing the rate of the residual biomass utilization as a fuel is its pyrolysis. The main benefits gained by the process are the increase of calorific value, the decrease of transport and storage costs, and the reduction of energy consumption required for grinding and milling. Biomass pyrolysis allows to decrease the moisture content below $3 \mathrm{wt} . \%$, while the calorific value and carbon content are increased by $15-25 \mathrm{wt} . \%$, which makes the produced (bio)char far more attractive than the feedstock used to its production [25].

The biomass-derived chars have great potential in lowering the net $\mathrm{CO}_{2}$ emissions of integrated (BF-BOF route) steel plants. The properties of chars produced by pyrolysis of biomass can be tailored in regard to the further application and supplementing stream (e.g., coke breeze for sintering, coal blend for cokemaking, coal injectant for the blast furnace, recarburizing of steel, etc.), thus resulting in optimal performance and greater value-in-use of the char [26]. Moreover, it would be a circular "return to basic", as, at the beginning of iron, and the next steel manufacture, this was biomass, which was used as a fuel for the process. However, the industrialization era made hard coal to be a so-far unbeatable material commonly applied in the metallurgical industry [27].

The substitution of $\mathrm{CB}$ with residual biomass char (or other bio residual/waste stream) in iron ore sintering processes can be the next step toward circular economy implementation [3]. The char formed during pyrolysis of bioresidues is characterized by significant carbon content, even up to $80 \mathrm{wt} . \%$, which is comparable with the C content in CB. This feature makes the material suitable for iron sintering processes. However, in order to substitute coke breeze with the (bio)char, the latter should also be characterized by low content of both volatile matter and ash. The preliminary research on the substitution of conventional fuels with biomass and biomass-derived materials are already available in the literature. There are several aspects which need to be taken into account while evaluating chars derived from biomass toward their use in iron sintering. These include composition, especially content of chlorine, alkali, and volatile matter, as well as emission.

The research on the impact of fuel mixture comprised of wood charcoal (WdCh), sawdust (SD), and coke breeze (CB) on final sinter quality and usability in metallurgical processes was carried out in [28]. It was shown that the share of SD in fuel streams comprising SD and CB should not exceed $10 \mathrm{wt} . \%$, while in the case of WdCh-CB and WdCh-SDCB fuel mixtures, the shares could be 30 wt. $\%-70$ wt. $\%$ and 20 wt. $\%-10$ wt. $\%-70$ wt. $\%$, respectively. The research also showed that the complete substitution of $\mathrm{CB}$ with biomassderived fuel was not possible because of the low energy density values. However, at the established substitutional fuel content, the properties of final sinter fulfilled the required quality standards [29]. In another study, the phase composition of sinters obtained by replacing a part of coke breeze (CB) with charcoal (Ch) or walnut shell (WnSh) substitute 
was examined. The stream of fuel applied in the research comprised of CB and 44 and 86 wt.\% of Ch or 35 and 42 wt.\% of WnSh. It was shown that the replacement of part of the $\mathrm{CB}$ in the sintering mixture with the biomass-based fuels changed the sintering conditions, which led to the change in ratio of some phases. However, regarding the composition of the final sinter, it was concluded that the use of studied fuels had no negative impact on the phase composition of produced sinters [30].

Research involving raw biomass and different biochars as substitutional fuels for the sintering process were also carried out together with investigation on the use of bituminous coal, pitch, and graphite for this purpose. According to the results, the obtained sinter was characterized by the desired quality, similar to one obtained with the use of coke breeze. However, it was found that, due to environmental emissions, the raw biomass could not be directly applied as a fuel for the sintering process, as its use would require the additional exhaust gas cleaning installation. The application of char, on the other hand, was more beneficial, as it improved the efficiency of the process while it limited the emission of $\mathrm{NO}_{\mathrm{x}}$, $\mathrm{SO}_{\mathrm{x}}$, and dusts. Nevertheless, biomass-derived char required additional monitoring of granulometric composition and moisture content, as the rate of its combustion could be too high [22].

As the raw biomass is shown to be unsuitable substitutional fuel for iron ore sintering, the pyrolyzed residual biomass can be considered for this purpose. However, one must take into account the type of the raw biomass, its affinity to and composition after pyrolysis, and its impact on sintering process emissions. In the article, the results of the research on the use of chars produced by pyrolysis of residual biomass (biochars) as a substitute of coke breeze in the iron sintering process are presented. Three types of biomass were examined, i.e., pelletized sawmill sawdust (SDP), woodchips (WdC), and sunflower husks $(\mathrm{SH})$. The effect of the alternative fuel impact on both sinter quality and usability in the metallurgical process, as well as environmental emissions, was checked. With regard to the latter, the system for exhaust gas cleaning was tested in relation to emission limitation. Moreover, processes involved in the research, i.e., biomass pyrolysis and iron ore sintering with the use of biochars, were carried out in pilot and semi-industrial-scale installations, respectively, to effectively simulate actual conditions and assess the obtained results. The improvement of environmental effects in the form of GHGs emission limitation in the proposed solution results from the fact that conventional fossil fuel-derived carbon is substituted with carbon of biomass origin. Hence, the limitation is proportional to the share of substitutional fuel in the sintering fuel stream. The same approach is stated for the pyrolysis process. The emission, which results from the combustion of volatile components released from biomass during pyrolysis (the energy source of the pyrolysis process), is also regarded as the emission from renewable sources.

\section{Materials and Methods}

\subsection{Preparation of Chars from Residual Biomass in Pilot-Scale Pyrolysis}

Residual sawmill sawdust (pelletized) (SDP), residual woodchips (WdC), and sunflower husks (SH) were used as feedstocks for biochars preparation. The characteristics of raw biomass materials are presented in Table 1.

Residual biomass chars were produced in pilot installation for conversion of solid fuels in a circulating fluidized bed, located in the Clean Coal Technologies Centre of the Institute for Chemical Processing of Coal (Zabrze, Poland) [31]. A photograph of part of the installation is shown in Figure 1. The pyrolysis of biomass of grain size $<10 \mathrm{~mm}$ was carried out in temperature $\sim 800{ }^{\circ} \mathrm{C}$ and with a capacity of $\sim 100 \mathrm{~kg}$ of biomass $/ \mathrm{h}$. 
Table 1. Characteristics of feedstock biomass materials used in the research.

\begin{tabular}{cccc}
\hline Parameter & $\begin{array}{c}\text { Residual Sawmill Sawdust } \\
\text { (Pellets) (SDP) }\end{array}$ & $\begin{array}{c}\text { Residual } \\
\text { Woodchips (WdC) }\end{array}$ & $\begin{array}{c}\text { Sunflower } \\
\text { Husks (SH) }\end{array}$ \\
\hline Grain size, mm & as Delivered & $<10 \mathrm{~mm}$ \\
Moisture content, wt.\% & $<10 \mathrm{~mm}$ & $<10 \mathrm{~mm}$ & 9.60 \\
Ash content, wt.\% & 41.7 & 22.1 & 3.90 \\
Volatile matter content, wt.\% & 8.61 & 0.33 & 66.7 \\
Fixed carbon content, wt.\% & 29.7 & 64.8 & 19.8 \\
\hline & 20.0 & 12.8 & \\
\hline C & & Elemental Composition, wt. $\%$ & \\
H & & Dry State & 53.8 \\
S & 59.4 & 51.4 & 6.02 \\
S & 4.81 & 5.36 & 0.94 \\
Cl calculed) & 0.68 & 0.21 & 0.14 \\
& 0.19 & 0.02 & 39.0 \\
\end{tabular}

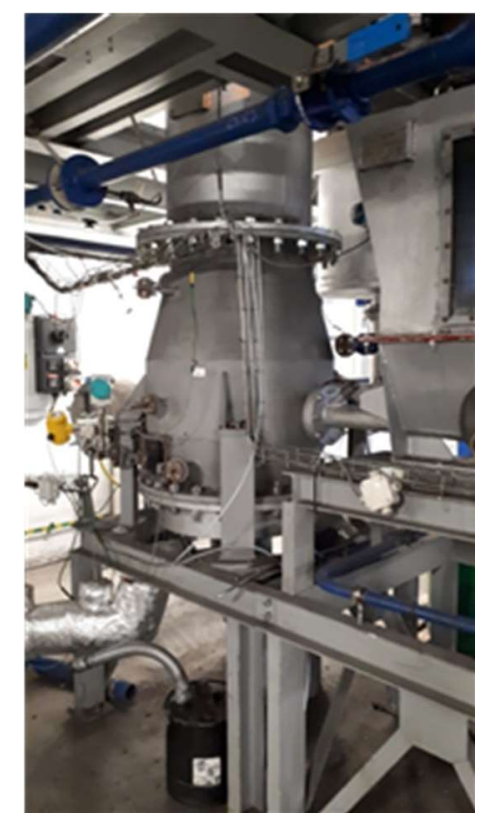

Figure 1. A photograph of part of the installation for solid fuels pyrolysis, located in the IChPW.

In the testing installation, due to the high flue gas velocities (5-10 m/s), part of the fluidized bed material (residual biomass) is lifted from the reactor by a riser pipe and, after being separated in a cyclone (which is an integral part of the system), it is returned to the bottom part of the reactor. Such implementation of the process allows for a significant increase in efficiency, an improvement of a fuel conversion rate, and a reduction of tar content in the generated gas.

\subsection{Semi-Industrial-Scale Iron Ore Sintering Process}

An iron ore sintering process was carried out in a semi-industrial-scale installation equipped with an exhaust gas neutralization system owned by the Łukasiewicz Research Network-Institute for Ferrous Metallurgy. The scheme of the installation is shown in Figure 2 [32]. 


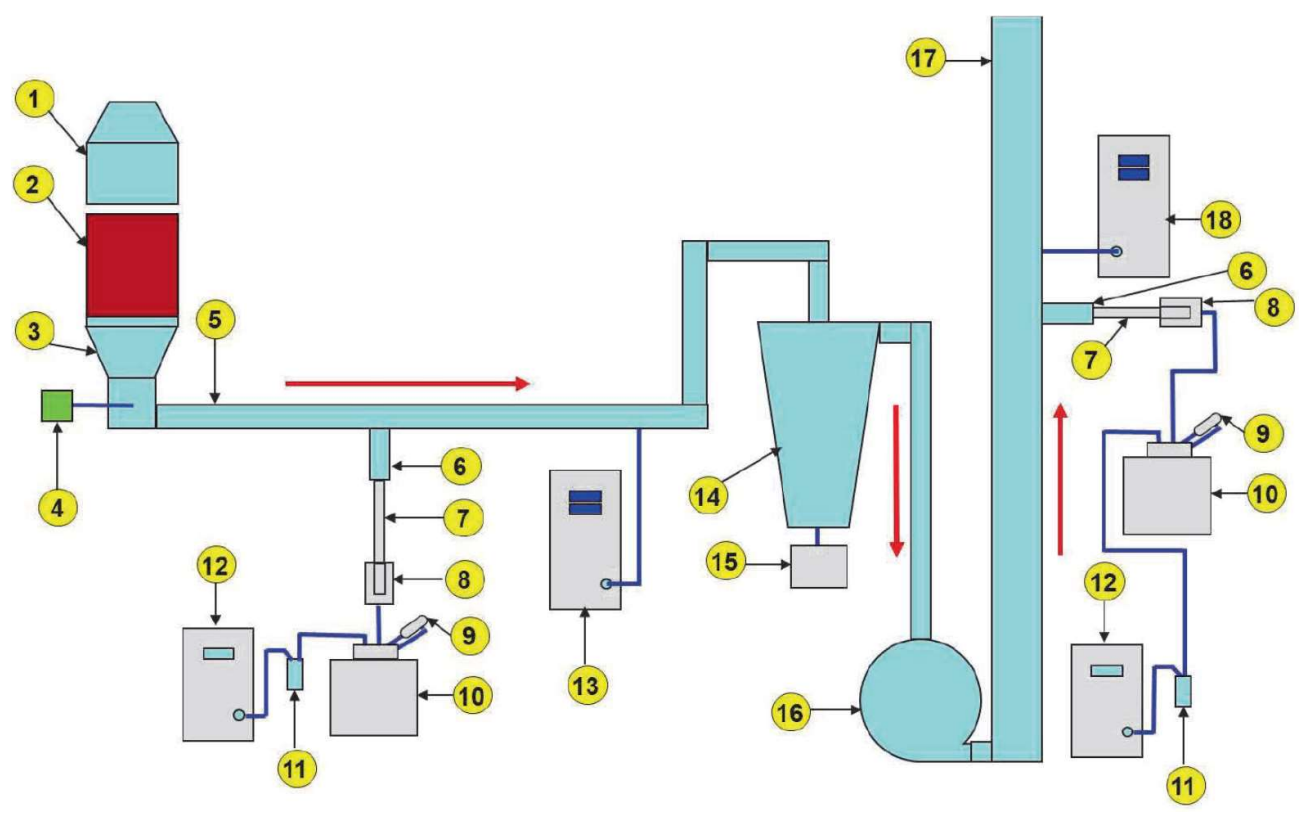

1. Burner

2. Sintering pan

3. Temperature measurement

4. Collection of dusts before the ceramic filter inlet

5. Flue gas pipeline

6. Sampling point (connector)

7. Probe with a thermostatic cloak

8. Celluloid filter (casing)

9. Absorber of organic compounds from gas phase
10. Cooler with a condensate collecting bottle

11. Moisture absorber

12. Suction pump with control system

13. Analyzer-continuous analysis on the "dirty" side

14. Ceramic filter (equipped with sorbent injection)

15. Collection of fluids from the ceramic filter tank

16. Exhaust fan

17. Chimney

18. Analyzer-continuous analysis on the "clean" side

Figure 2. The scheme of the semi-industrial-scale installation for sintering of iron ores and wastes.

The semi-industrial sintering installation comprises a sintering site equipped with sintering pans of working height 550 and $300 \mathrm{~mm}$ and an ignition furnace of power $250 \mathrm{~kW}$. The gas cleaning process is carried out using a catalytic ceramic filter of high thermal resistance, which allows for cleaning of gases of temperature up to $400{ }^{\circ} \mathrm{C}$. The filter (Figure 2(14)) is additionally equipped with a sorbent dosing system for the improved neutralization of harmful gas components (Figure 3). In the current research, hydrated lime sorbent (HLS) (CAS 1305-62-0) was used.

Sintering process tests were carried out with the use of all procedures and conditions applied for industrial sintering belts operated at integrated steel plants, i.e., the composition of sintering mixture, the retention time in ignition furnace, underpressure, the sintering mixture height, calcium oxide addition, mixture basicity, and amount of sinter return. A sintering mixture of the following parameters was used: the ratio of hematite ore to magnetite concentrate -0.82 , basicity $\left(\mathrm{CaO} / \mathrm{SiO}_{2}\right)-1.2$, and magnesium oxide $(\mathrm{MgO})$ content-1.3 wt.\%.

In Table 2, the chemical composition of particular components of the sintering mixture used in the research is shown, while in Table 3, the final properties of the sintering mixtures used in the tests are presented. 

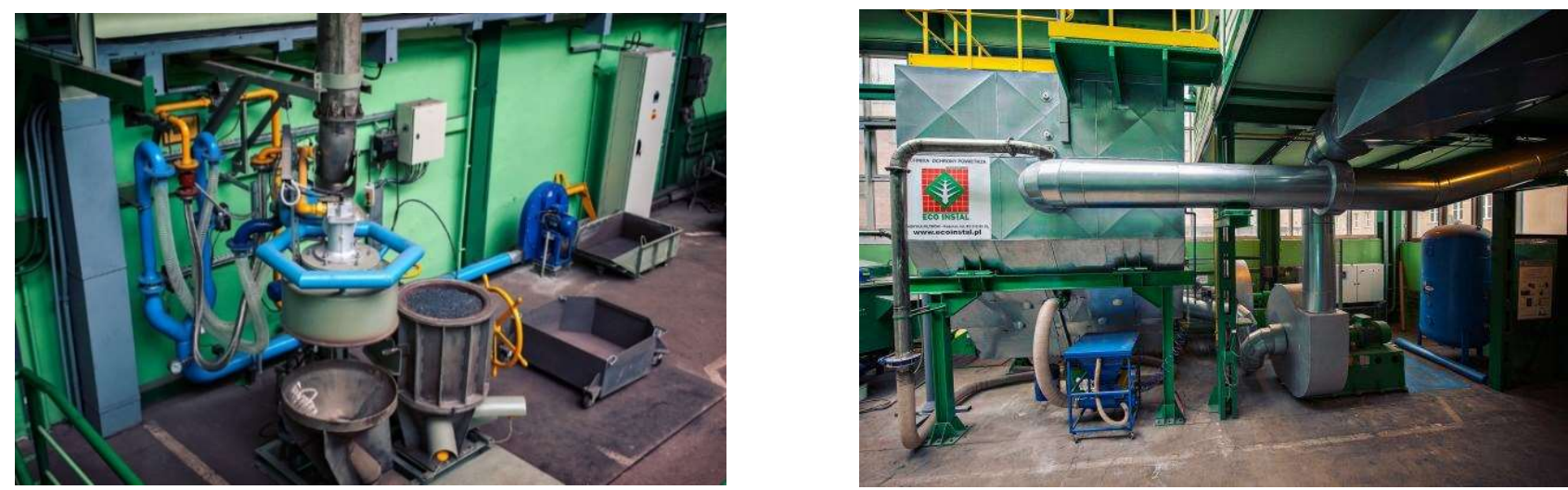

Figure 3. Semi-industrial-scale installation for sintering of iron ores and wastes (Left) equipped with a gas cleaning system (Right).

Table 2. Chemical composition of sintering mixture components.

\begin{tabular}{|c|c|c|c|c|c|c|c|c|c|c|c|}
\hline Component & $\begin{array}{c}\mathrm{Fe}, \\
\text { wt.\% }\end{array}$ & $\begin{array}{l}\mathrm{Fe}^{2+} \\
\text { wt. } \%\end{array}$ & $\begin{array}{l}\mathrm{SiO}_{2}, \\
\text { wt. } \%\end{array}$ & $\begin{array}{l}\mathrm{CaO}, \\
\text { wt.\% }\end{array}$ & $\begin{array}{c}\mathrm{Al}_{2} \mathrm{O}_{3}, \\
\text { wt.\% }\end{array}$ & $\begin{array}{l}\mathrm{MgO}, \\
\text { wt.\% }\end{array}$ & $\begin{array}{c}\text { S, } \\
\text { wt. } \%\end{array}$ & $\begin{array}{l}\mathrm{K}_{2} \mathrm{O} \text {, } \\
\text { wt.\% }\end{array}$ & $\begin{array}{c}\mathrm{Na}_{2} \mathrm{O} \text {, } \\
\text { wt. } \%\end{array}$ & $\begin{array}{c}\mathrm{Cl}, \\
\text { wt. } \%\end{array}$ & $\begin{array}{r}\text { Zn, } \\
\text { wt.\% }\end{array}$ \\
\hline Hematite ore & 61.7 & 0.57 & 9.97 & 0.081 & 0.68 & 0.120 & 0.012 & 0.013 & 0.21 & 0.24 & 0.006 \\
\hline Magnetite concentrate & 65.7 & 27.00 & 8.00 & 0.140 & 0.17 & 0.351 & 0.035 & 0.021 & 0.027 & 0.014 & 0.003 \\
\hline Burnt lime & 0.63 & 0.00 & 0.50 & 95.40 & 0.07 & 0.30 & 0.000 & 0.0 & 0.0 & 0.0 & 0.02 \\
\hline Limestone & 1.25 & 0.50 & 0.94 & 53.92 & 0.34 & 0.59 & 0.149 & 0.0 & 0.0 & 0.0130 & 0.01 \\
\hline Dolomite & 2.21 & 0.80 & 0.86 & 31.60 & 0.19 & 20.3 & 0.030 & 0.0 & 0.0 & $<0.010$ & 0.1 \\
\hline
\end{tabular}

Table 3. Final properties of the sintering mixtures used in the tests.

\begin{tabular}{|c|c|c|c|c|c|c|c|c|}
\hline \multirow{2}{*}{ Parameter } & \multirow{2}{*}{ Unit } & \multirow{2}{*}{$\begin{array}{l}\text { Comparative Sinter, } 100 \% \text { of } \\
\text { Coke Breeze in the Fuel }\end{array}$} & \multicolumn{2}{|c|}{$\begin{array}{l}\text { Biochar from Residual } \\
\text { Pelletized Sawdust }\end{array}$} & \multicolumn{2}{|c|}{$\begin{array}{l}\text { Biochar from Residual } \\
\text { Wood Chips }\end{array}$} & \multicolumn{2}{|c|}{$\begin{array}{c}\text { Biochar from } \\
\text { Sunflower Husks }\end{array}$} \\
\hline & & & $\begin{array}{l}\text { Low } \\
\text { Share }\end{array}$ & High Share & $\begin{array}{l}\text { Low } \\
\text { Share }\end{array}$ & $\begin{array}{l}\text { High } \\
\text { Share }\end{array}$ & $\begin{array}{l}\text { Low } \\
\text { Share }\end{array}$ & $\begin{array}{l}\text { High } \\
\text { Share }\end{array}$ \\
\hline Hematite ore & $\mathrm{kg}$ & 46.99 & 47.02 & 47.04 & 47.05 & 47.02 & 47.05 & 47.05 \\
\hline Magnetite concentrate & $\mathrm{kg}$ & 59.91 & 59.95 & 59.98 & 60.00 & 59.96 & 60.00 & 60.00 \\
\hline Limestone & $\mathrm{kg}$ & 16.90 & 16.91 & 16.92 & 16.92 & 16.91 & 16.92 & 16.92 \\
\hline Dolomite & $\mathrm{kg}$ & 5.44 & 5.45 & 5.45 & 5.45 & 5.45 & 5.45 & 5.45 \\
\hline Burnt lime & $\mathrm{kg}$ & 1.87 & 1.87 & 1.87 & 1.87 & 1.87 & 1.87 & 1.87 \\
\hline Returned sinter & $\mathrm{kg}$ & 56.16 & 56.20 & 56.22 & 56.24 & 56.20 & 56.24 & 56.24 \\
\hline Fuel—coke breeze & $\mathrm{kg}$ & 6.12 & 5.39 & 4.73 & 5.28 & 4.78 & 5.28 & 4.69 \\
\hline Fuel-biochar & $\mathrm{kg}$ & 0.00 & 0.64 & 1.26 & 0.62 & 1.25 & 0.71 & 1.43 \\
\hline Fuel share in mixture & wt. $\%$ & 4.91 & 4.80 & 4.73 & 4.69 & 4.78 & 4.69 & 4.69 \\
\hline Moisture content in mixture & wt. $\%$ & 6.92 & 6.94 & 6.95 & 6.91 & 6.92 & 6.89 & 6.92 \\
\hline Permeability (flow resistance) & $\mathrm{s}$ & 5.40 & 5.40 & 5.20 & 5.30 & 5.33 & 5.30 & 5.40 \\
\hline
\end{tabular}

Sintering tests were carried out using fuel mixtures (i.e., biochar and coke breeze) of low ( 12.3 wt.\%) and high ( 27.8 wt.\%) average shares of biochars, as well as with the use of fuel stream composed of only coke breeze. The determination of physicochemical properties of materials (sintering mixtures and sinters) was performed using standards including:

- BN-84/0604-13-Determination of physical properties of iron ores, their concentrates, sinters, and lumps. Samples collection and preparation.

- ISO-4701:2019-Iron ores and direct reduced iron—determination of size distribution by sieving.

- PN-ISO 3082:2002-Iron ores-procedures for samples collection and preparation.

- $\quad \mathrm{PN}-93 / \mathrm{H}-04062$-Iron ores-determination of bulk density.

- ISO-3097/74-Determination of humidity of magnetite concentrates.

The sintering process procedure was in accordance with standard PN-ISO 8263:1999Iron ore fines-method for sintering test result presentation. 


\section{Results and Discussion}

\subsection{Physicochemical Properties of Residual Biomass-Derived Chars}

The chars produced from different residual biomass types were characterized according to grain size, bulk density, and chemical composition. The grain size is one of the factors that significantly affects the course of $\mathrm{CB}$ combustion. Many studies and industrial practices show that coarse-grained $\mathrm{CB}$ causes delayed combustion, which leads to higher heat energy consumption during the process. On the other hand, fine-grained fuel reduces permeability of the sinter mix and, therefore, the efficiency of the process itself. Due to this fact, the use of CB fraction with grains sized below $1 \mathrm{~mm}$ is avoided. In Figure 4, photographs of produced chars are presented together with average grain size (AGS).
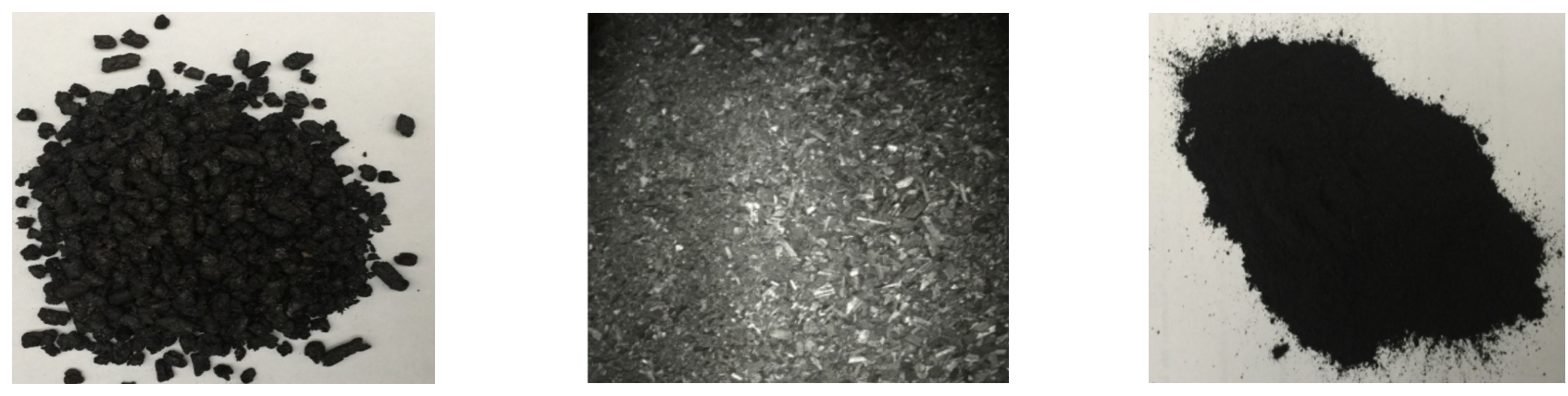

Figure 4. Chars derived from: (Left)—pelletized sawmill sawdust (AGS = $3.37 \mathrm{~mm}$ ), (Middle)—wood chips $($ AGS $=1.26 \mathrm{~mm})$, and $($ Right $)$ —sunflower husks $($ AGS $=0.28 \mathrm{~mm})$.

In Table 4, the grain size analysis results are presented together with the characteristics of coke breeze conventionally used as a fuel for ores sintering processes, while in Figure 5, the overall share of smallest (undesired) grain fraction of biochars and coke breeze is presented.

Table 4. Grain size analysis and bulk densities of biochars and coke breeze.

\begin{tabular}{|c|c|c|c|c|}
\hline \multirow[b]{2}{*}{ Grain Size Class, mm } & \multicolumn{4}{|c|}{ Grain Size Analysis, wt.\% } \\
\hline & $\begin{array}{l}\text { Biochar from Residual } \\
\text { Pelletized Sawdust (SDP) }\end{array}$ & $\begin{array}{l}\text { Biochar from Residual } \\
\text { Wood Chips (WdC) }\end{array}$ & $\begin{array}{c}\text { Biochar from Sunflower } \\
\text { Husks (SH) }\end{array}$ & Coke Breeze (CB) \\
\hline below 0.10 & 0.64 & 5.71 & 19.84 & 9.18 \\
\hline $0.10 \div 0.16$ & 0.72 & 2.42 & 13.17 & 7.30 \\
\hline $0.16 \div 0.20$ & 0.52 & 2.71 & 10.46 & 6.08 \\
\hline $0.20 \div 0.315$ & 2.25 & 7.38 & 30.14 & 10.92 \\
\hline $0.315 \div 0.40$ & 2.25 & 7.46 & 12.13 & 8.53 \\
\hline $0.40 \div 0.50$ & 2.98 & 5.54 & 5.93 & 4.73 \\
\hline $0.50 \div 0.63$ & 2.98 & 5.42 & 3.14 & 4.22 \\
\hline $0.63 \div 0.80$ & 4.06 & 9.80 & 1.77 & 5.12 \\
\hline $0.80 \div 1.00$ & 0.40 & 2.67 & 1.04 & 3.12 \\
\hline $1.00 \div 2.00$ & 9.07 & 28.30 & 1.71 & 14.57 \\
\hline $2.00 \div 3.15$ & 20.61 & 19.84 & 0.35 & 11.28 \\
\hline $3.15 \div 4.00$ & 8.79 & 1.88 & 0.22 & 5.20 \\
\hline $4.00 \div 5.00$ & 25.36 & 0.42 & 0.08 & 5.02 \\
\hline $5.00 \div 6.30$ & 17.96 & 0.33 & 0.00 & 3.39 \\
\hline above 6.3 & 1.41 & 0.1 & 0.0 & 1.3 \\
\hline Average grain size & 3.37 & 1.26 & 0.28 & 1.45 \\
\hline Bulk density, $\mathrm{kg} / \mathrm{m}^{3}$ & 148.9 & 273.1 & 408.7 & 759.9 \\
\hline
\end{tabular}




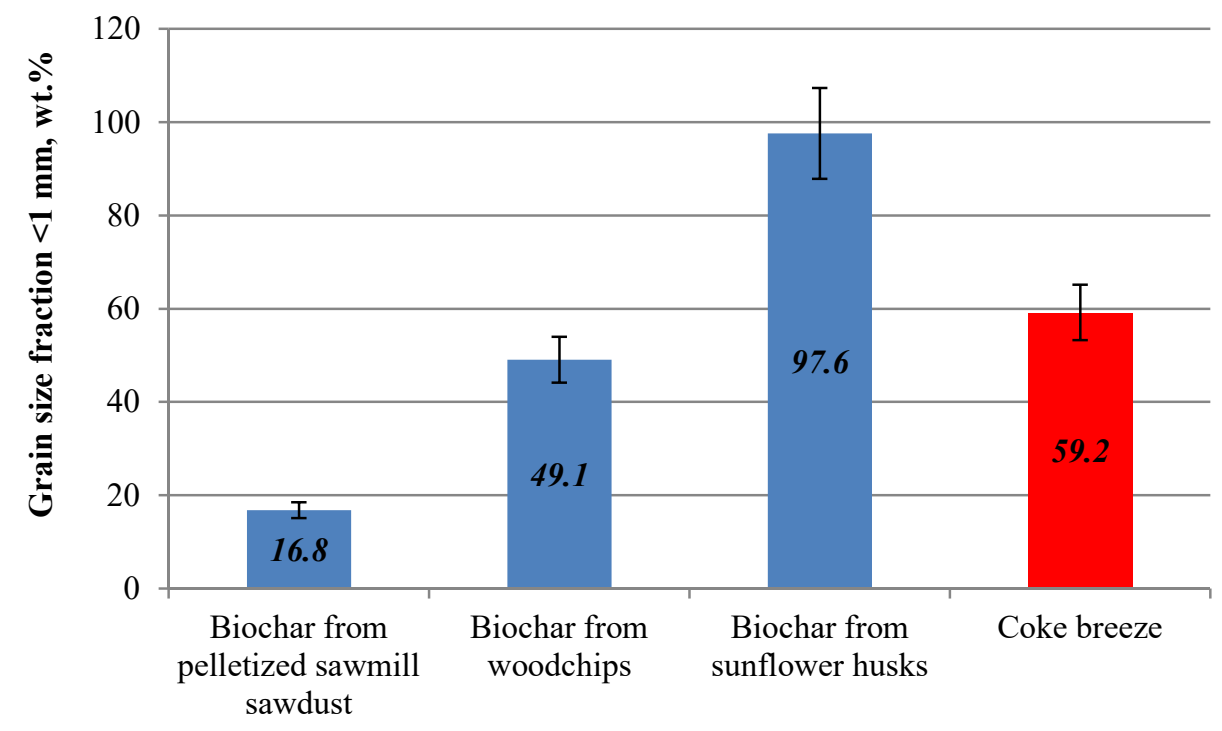

Figure 5. The share of undesired grain size fraction $<1 \mathrm{~mm}$ for particular biochars and coke breeze.

The smallest size of grains was measured for biochar from $\mathrm{SH}$, for which the average grain size was equal to $0.28 \mathrm{~mm}$, while the share of fractions $<1 \mathrm{~mm}$ reached ca. $98 \mathrm{wt} . \%$. The biochar from $\mathrm{WdC}$ was characterized by grain size similar to $\mathrm{CB}$, with average value equal to $1.26 \mathrm{~mm}$ (for $\mathrm{CB}$ it was $1.45 \mathrm{~mm}$ ). However, the share of smallest grain fraction $<1 \mathrm{~mm}$ was slightly lower than in the case for coke breeze, and reached ca. $50 \mathrm{wt} . \%$ (60 wt.\% for CB), which was advantageous. The best granularity with regard to sintering process preferences was obtained for biochar from residual SDP. Its average grain size reached $3.37 \mathrm{~mm}$, with a very low content of smallest grain fraction $<1 \mathrm{~mm}$ of $17 \mathrm{wt} . \%$. Such granularity of the fuel, according to literature data [18], was expected to positively influence the permeability of the sintering mixture.

In Table 5, the chemical composition of biochars and coke breeze is presented.

Table 5. Chemical composition of biochars and coke breeze.

\begin{tabular}{ccccc}
\hline Parameter, wt. $\%$ & $\begin{array}{c}\text { Biochar from Residual } \\
\text { Pelletized Sawdust (SDP) }\end{array}$ & $\begin{array}{c}\text { Biochar from Residual } \\
\text { Wood Chips (WdC) }\end{array}$ & $\begin{array}{c}\text { Biochar from } \\
\text { Sunflower Husks (SH) }\end{array}$ & Coke Breeze (CB) \\
\hline $\mathrm{C}$ & 82.0 & 75.0 & 73.0 & 83.8 \\
Volatile matter & 9.70 & 25.0 & 20.2 & 1.58 \\
$\mathrm{SiO}_{2}$ & 3.24 & 0.64 & 0.48 & 6.24 \\
$\mathrm{CaO}$ & 0.66 & 0.90 & 1.66 & 1.55 \\
$\mathrm{~K}$ & 0.15 & 0.16 & 1.43 & 0.04 \\
$\mathrm{Na}$ & $<0.01$ & 0.019 & $<0.01$ & 0.12 \\
$\mathrm{Cl}$ & 0.02 & 0.04 & 0.09 & 0.08 \\
$\mathrm{Cu}$ & $<0.01$ & $<0.01$ & 0.03 & 0.01 \\
$\mathrm{Fe}$ & 0.59 & 0.17 & 0.24 & 1.73 \\
$\mathrm{Zn}$ & $<0.01$ & 0.01 & 0.013 & 0.01 \\
$\mathrm{~S}$ & 0.31 & 0.33 & 0.15 & 0.90 \\
$\mathrm{Al}_{2} \mathrm{O}_{3}$ & 0.067 & 0.068 & 0.043 & 3.36 \\
$\mathrm{MgO}$ & 4.36 & 0.23 & 1.33 & 0.48 \\
\hline
\end{tabular}

The content of elemental carbon in biochars from SDP (82 wt.\%) was comparable to the parameter value in $\mathrm{CB}(83.8 \mathrm{wt} . \%)$, while in the case of biochars from $\mathrm{WdC}$ and $\mathrm{SH}$, the value of the parameter was lower and reached $75 \mathrm{wt} . \%$ and $73 \mathrm{wt} . \%$, respectively. Moreover, all biochars were characterized by elevated content of volatile matter (from 9.7 to $25 \mathrm{wt} . \%)$ with regard to the CB characteristic (1.58 wt.\%). The high content of volatile 
matter was not advantageous due to both technological issues of sintering process reported in literature and the increase of hydrocarbons content in the exhaust gas.

On the other hand, the lower content of ballast, i.e., $\mathrm{SiO}_{2}$ (from 0.48 to $3.24 \mathrm{wt}$ \%), in comparison with CB (6.24 wt.\%), was the beneficial feature of all produced biochars. Moreover, relatively high content of $\mathrm{CaO}$ in biochars (from 0.66 to $1.66 \mathrm{wt}$.\%) would allow for the reduction of the required amount of additional flux (calcium oxide), which was also favorable. With regard to $\mathrm{CaO}$ and $\mathrm{SiO}_{2}$ balance, related to the fuel basicity, the best composition was observed for biochar from SH (1.66 wt. $\% \mathrm{CaO}$ and 0.48 wt. $\% \mathrm{SiO}_{2}$ ), and the next was for biochar from $\mathrm{WdC}\left(0.90 \mathrm{wt} . \% \mathrm{CaO}\right.$ and $0.64 \mathrm{wt} . \%$ of $\left.\mathrm{SiO}_{2}\right)$, while in the case of biochar from SDP, it was not so beneficial, as the content of $\mathrm{CaO}$ was $0.66 \mathrm{wt}$. $\%$ at $\mathrm{SiO}_{2}$ content 3.24 wt.\%.

Another advantageous feature of biochars was the very low content of substances undesired in the sintering process, i.e., sodium, zinc, and copper. Despite this fact, it was noticed that the content of potassium in all biochars, especially in one derived from sunflower husks, was quite high in the range of $0.15 \mathrm{wt} \%$ to $1.43 \mathrm{wt} . \%$. Both sodium and potassium are found to cause problems in the dedusting stage of gas cleaning, as when they react with chlorine the resistance of dust to separation increases, and thus the efficiency of electrofilters decreases. The final advantage of biochars was related to the low content of sulfur, which was in the range of 0.15 to $0.33 \mathrm{wt} . \%$, while the value determined for CB was 0.9 wt. $\%$.

Considering the physicochemical composition of produced biochars (especially grain size and volatile matter content), it was concluded that materials derived from pelletized residual sawdust and residual wood chips would be the most preferable fuel for iron ore sintering processes. Nevertheless, tests with the use of all types of biochars were carried out.

\subsection{The Impact of Biochars on Sintering Process Parameters and Sinter Properties}

In Table 6, the parameters of the sintering process and the properties of produced sinters obtained at different (low $\sim 12.3 \mathrm{wt} . \%$ and high $\sim 27.8 \mathrm{wt} . \%$ ) share of biochars in the fuel are presented. The sintering processes were repeated three times (or more, if significant differences in obtained results were observed) and the presented results are the averaged values. The detailed experimental data can be found in Table A1, presented in Appendix A.

The data shown in Table 6 indicates that the substitution of CB fuel with biochars in the investigated range leads to production of sinter of properties mostly comparable to ones observed for conventionally produced material. The key parameters crucial for evaluation of the sintering process (productivity, fuel consumption) and most advantageous effects resulting from biochars use are discussed below.

It was observed that the introduction of $27.8 \mathrm{wt} . \%$ SDP biochar to the fuel stream increased the production efficiency by $5.6 \%$, i.e., from $37.73 \mathrm{Mg} / \mathrm{m}^{2} / 24 \mathrm{~h}$ to $39.86 \mathrm{Mg} / \mathrm{m}^{2} / 24 \mathrm{~h}$. In the case of $12.3 \mathrm{wt}$.\% share of pyrolyzed $\mathrm{WdC}$, the production efficiency was higher by $2.5 \%$ (it increased from $37.73 \mathrm{Mg} / \mathrm{m}^{2} / 24 \mathrm{~h}$ for CB to $38.66 \mathrm{Mg} / \mathrm{m}^{2} / 24 \mathrm{~h}$ for mixed fuel). The high share of biochar from sunflower husks in the fuel caused the production efficiency decrease of $9.3 \%$ (from $37.73 \mathrm{Mg} / \mathrm{m}^{2} / 24 \mathrm{~h}$ for $\mathrm{CB}$ to $34.20 \mathrm{Mg} / \mathrm{m}^{2} / 24 \mathrm{~h}$ for mixed fuel). Hence, it was concluded that, with regard to production efficiency, the share of substitutional fuel in the fuel stream should not exceed $\sim 30 \mathrm{wt} . \%$ in the case of biochars derived from residual SDP or residual WdC, while in the case of biochar from $\mathrm{SH}$, its share in fuel had to be kept below $10 \mathrm{wt} . \%$.

In the case of fuel consumption, it was observed that at the lower share of biochars in the fuel stream, the parameter value increased by max. $1.3 \%$ with the use of biochar from residual SDP, while it decreased by $2.2 \%$ with the use of pyrolyzed WdC. The noticeable increase of fuel consumption was noted for all fuel streams containing higher shares of biochars, and it was in the range of 1.5\% for biochar from SDP to 3.7\% for biochar from SH (a 2.3\% increase was noted for biochar from residual $\mathrm{WdC}$ ). Thus, with regard to unit fuel consumption, it was concluded, similarly as in the case of production efficiency, that the share of substitutional fuel in the fuel stream should not exceed $\sim 30 \mathrm{wt} . \%$ in the case of 
biochars derived from residual SDP or residual $\mathrm{WdC}$, while in the case of char from $\mathrm{SH}$, its share in fuel had to be kept below $10 \mathrm{wt} . \%$.

Table 6. The results of the laboratory sintering tests with low and high share of biochar in fuel.

\begin{tabular}{|c|c|c|c|c|c|c|c|c|c|}
\hline & \multirow[t]{2}{*}{ Parameter } & \multirow[t]{2}{*}{ Unit } & \multirow{2}{*}{$\begin{array}{c}\text { Comparative Sinter, } \\
100 \% \text { of Coke Breeze in } \\
\text { the Fuel }\end{array}$} & \multicolumn{2}{|c|}{$\begin{array}{l}\text { Biochar from } \\
\text { Residual Pelletized } \\
\text { Sawdust (SDP) }\end{array}$} & \multicolumn{2}{|c|}{$\begin{array}{l}\text { Biochar from } \\
\text { Residual Wood } \\
\text { Chips (WdC) }\end{array}$} & \multicolumn{2}{|c|}{$\begin{array}{c}\text { Biochar from } \\
\text { Sunflower Husks } \\
\text { (SH) }\end{array}$} \\
\hline & & & & $\begin{array}{l}\text { Low } \\
\text { Share }\end{array}$ & $\begin{array}{l}\text { High } \\
\text { Share }\end{array}$ & $\begin{array}{l}\text { Low } \\
\text { Share }\end{array}$ & $\begin{array}{l}\text { High } \\
\text { Share }\end{array}$ & $\begin{array}{l}\text { Low } \\
\text { Share }\end{array}$ & $\begin{array}{l}\text { High } \\
\text { Share }\end{array}$ \\
\hline \multirow{5}{*}{ 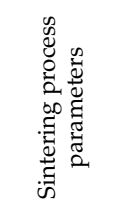 } & \multirow{5}{*}{$\begin{array}{l}\text { Sintering time } \\
\text { Production efficiency } \\
\text { Unit consumption of } \\
\text { coke breeze } \\
\text { Unit consumption of a } \\
\text { biochar } \\
\text { Total fuel consumption }\end{array}$} & $\min$ & 21.43 & 19.85 & 19.54 & 20.58 & 20.71 & 21.53 & 22.77 \\
\hline & & $\mathrm{Mg} / \mathrm{m}^{2} / 24 \mathrm{~h}$ & 37.73 & 39.62 & 39.86 & 38.66 & 37.65 & 36.51 & 34.20 \\
\hline & & $\mathrm{kg} / \mathrm{Mg}$ of sinter & 57.8 & 52.4 & 46.4 & 50.6 & 46.9 & 51.3 & 46.0 \\
\hline & & $\mathrm{kg} / \mathrm{Mg}$ of sinter & 0.0 & 6.2 & 12.3 & 5.9 & 12.3 & 6.9 & 14.0 \\
\hline & & $\mathrm{kg} / \mathrm{Mg}$ of sinter & 57.83 & 58.60 & 58.70 & 56.53 & 59.16 & 58.20 & 59.99 \\
\hline \multirow{14}{*}{ 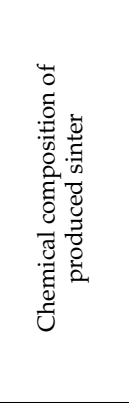 } & $\mathrm{Fe}$ & wt. \% & 54.03 & 54.10 & 54.35 & 54.58 & 54.40 & 54.43 & 54.21 \\
\hline & $\mathrm{FeO}$ & wt.\% & 9.30 & 7.13 & 6.32 & 6.30 & 6.40 & 6.18 & 5.46 \\
\hline & $\mathrm{SiO}_{2}$ & wt. \% & 10.32 & 10.28 & 10.25 & 9.73 & 8.95 & 9.75 & 8.61 \\
\hline & $\mathrm{CaO}$ & wt. $\%$ & 11.21 & 11.22 & 10.92 & 11.15 & 11.43 & 11.09 & 11.37 \\
\hline & $\mathrm{Al}_{2} \mathrm{O}_{3}$ & wt. $\%$ & 0.60 & 0.59 & 0.56 & 0.57 & 0.58 & 0.58 & 0.57 \\
\hline & $\mathrm{TiO}_{2}$ & wt. $\%$ & 0.019 & 0.017 & 0.019 & 0.019 & 0.019 & 0.018 & 0.019 \\
\hline & $\mathrm{MgO}$ & wt. $\%$ & 1.32 & 1.33 & 1.31 & 1.24 & 1.22 & 1.26 & 1.30 \\
\hline & $\stackrel{\mathrm{P}}{\mathrm{P}}$ & wt. $\%$ & 0.023 & 0.024 & 0.021 & 0.024 & 0.024 & 0.023 & 0.026 \\
\hline & Mn & wt. $\%$ & 0.032 & 0.033 & 0.016 & 0.029 & 0.165 & 0.030 & 0.029 \\
\hline & S & wt. $\%$ & 0.019 & 0.023 & 0.024 & 0.035 & 0.034 & 0.031 & 0.030 \\
\hline & $\mathrm{K}_{2} \mathrm{O}$ & wt. $\%$ & 0.023 & 0.025 & 0.023 & 0.029 & 0.029 & 0.033 & 0.044 \\
\hline & $\mathrm{Na}_{2} \mathrm{O}$ & wt. $\%$ & 0.034 & 0.033 & 0.030 & 0.037 & 0.036 & 0.036 & 0.034 \\
\hline & $\mathrm{Zn}$ & wt.\% & 0.010 & 0.010 & 0.010 & 0.010 & 0.009 & 0.010 & 0.010 \\
\hline & $\mathrm{Cl}$ & wt. $\%$ & 0.007 & 0.005 & 0.005 & 0.010 & 0.009 & 0.006 & 0.005 \\
\hline \multirow{6}{*}{$\begin{array}{l}\text { Grain size } \\
\text { analysis of } \\
\text { produced } \\
\text { sinter }\end{array}$} & $>40 \mathrm{~mm}$ & wt. $\%$ & 13.54 & 12.55 & 12.18 & 11.07 & 11.47 & 12.61 & 12.44 \\
\hline & $>25 \mathrm{~mm}$ & wt. $\%$ & 20.47 & 22.80 & 22.55 & 25.11 & 25.10 & 24.86 & 26.05 \\
\hline & $>15 \mathrm{~mm}$ & wt. $\%$ & 21.42 & 21.94 & 21.13 & 22.31 & 22.30 & 21.35 & 20.98 \\
\hline & $>10 \mathrm{~mm}$ & wt. $\%$ & 17.97 & 16.59 & 17.31 & 16.56 & 17.18 & 16.96 & 16.31 \\
\hline & $>5 \mathrm{~mm}$ & wt. $\%$ & 26.60 & 26.12 & 26.84 & 24.94 & 23.94 & 24.21 & 24.23 \\
\hline & Median & $\mathrm{mm}$ & 17.06 & 17.78 & 17.29 & 18.24 & 18.39 & 18.54 & 18.88 \\
\hline \multirow{2}{*}{$\begin{array}{l}\text { Sinter } \\
\text { strength }\end{array}$} & \multirow{2}{*}{$\begin{array}{c}\text { Strength ISO T }>6.3 \mathrm{~mm} \\
\text { Abrasion ISO } \\
\mathrm{A}<0.5 \mathrm{~mm}\end{array}$} & wt. $\%$ & 68.17 & 69.82 & 70.57 & 70.76 & 69.18 & 70.58 & 69.59 \\
\hline & & wt. $\%$ & 5.80 & 5.59 & 5.57 & 5.61 & 5.56 & 5.69 & 5.66 \\
\hline RDI & $<3.15 \mathrm{~mm}$ & wt.\% & 17.7 & 15.6 & 16.4 & 13.8 & 12.2 & 16.1 & 17.4 \\
\hline RI & $\mathrm{dR} / \mathrm{dt}(\mathrm{O} / \mathrm{Fe}=0.9)$ & $\% / \min$ & 0.96 & 0.98 & 1.09 & 1.13 & 1.17 & 1.12 & 1.14 \\
\hline
\end{tabular}

A very interesting phenomenon noted for all sinters produced with the use of substitutional fuel was the decrease of $\mathrm{FeO}$ content in comparison to sinter produced with the use of CB only, for which the value of parameter was $9.3 \mathrm{wt} . \%$. In the case of low shares of biochars in the fuel stream, the content of $\mathrm{FeO}$ in final sinters varied from 6.18 to $7.13 \mathrm{wt} . \%$, while at high shares of biochars in the fuel stream, it was even lower and ranged from 5.46 to $6.40 \mathrm{wt} . \%$. With regard to further BF processing of sinters, it is a very desired feature, as sinters of lower $\mathrm{FeO}$ content reveal better reductive properties and, thus, the smaller amount of coke is required for metallic iron recovery. The better reducibility of sinters produced with the use of biochars was confirmed by determination of reducibility index (RI), which showed that the $\mathrm{dR} / \mathrm{dt}$ ratio of sinters with biochars containing fuel was in the range from 0.98 to $1.17 \% / \mathrm{min}$, while for sinter produced with CB fuel, it was $0.96 \% / \mathrm{min}$. The measurements of reduction degradation index (RDI) also showed the more advantageous properties of sinters produced with the use of biochars, which revealed better resistance towards reductive conditions. The lower value of RDI index is preferable, as it means that the sinter is less vulnerable to crushing and formation of fraction $<3.15 \mathrm{~mm}$ at $\mathrm{BF}$ operational conditions. In the discussed research, the sinter produced with the use of only CB contained $17.7 \mathrm{wt} . \%$ of fraction $<15 \mathrm{~mm}$, while for sinters produced with the use of biochars it was 13.8-16.1 wt.\% (for low shares in the fuel stream) and from 12.2-17.4 wt.\% (for high shares in the fuel stream).

Other beneficial features of the use of biochars in the sintering process were much lower levels of alkalis, chlorine, and zinc in the produced sinter. The sinters produced with the biochars also revealed better strength, measured as ISO T (the share of grain fraction $>6.3 \mathrm{~mm}$ [33]). The highest value of the parameter was obtained for low share of char 
from residual $\mathrm{WdC}$ and reached $70.76 \mathrm{wt} . \%$, and the next highest was for the low share of char from SDP, i.e., $70.57 \mathrm{wt} . \%$, while for the sinter produced with the use of CB only, it was 68.17 wt.\%. Simultaneously, abrasion ISO A (the share of fraction $<0.5 \mathrm{~mm}$ [33]) was practically the same as the one measured for sinter produced with the conventional fuel. This was even more interesting due to the fact that the ISO T and ISO A were usually worsening at lowering $\mathrm{FeO}$ content in the sinter, as, according to the practice, the better reducibility is, the worse the strength of the sinter observed. Hence, the use of biochars in sinter production could actually improve both strength and reduction properties of the final product.

These observations are in agreement with other research discussed in the literature. For example, in [34], biochar powder with grain size of 5-10 $\mathrm{mm}$ was used to replace $6 \mathrm{wt} . \%$ and $12 \mathrm{wt} . \%$ of CB in the fuel and it was found that the sinter products could meet the requirements of blast furnace, although the tumble strength was reduced. In research involving the use of straw-derived biochar, due to different combustibility of $\mathrm{CB}$ and biomaterial, there was a considerable degradation in sinter quality when more than $20 \mathrm{wt.} \%$ of CB was substituted [35]. In the review on biochar use in metallurgy [36], the authors state that the use of biochar in the sintering stage enabled higher sintering productivity, but led to weaker strength of sinter, which was opposite to the discussed research. However, the cases discussed in the review cover up to $40 \mathrm{wt} . \%$ share of biochar in the fuel stream. Thus, it can be concluded that the usability of biochar in sintering processes possesses individual character, as it strongly depends on biochar quality and its amount in the fuel stream.

\subsection{The Impact of Chars Derived from Residual Biomass on Flue Gases Properties}

The impact of a given fuel on a sintering process has to be recognized not only in regard to the final sinter properties, but also in regard to environmental aspects, including emissions. Hence, during the performance of sintering tests, the continuous analyses of exhaust gas before and after catalytic ceramic filter were carried out, covering the parameters such as $\mathrm{O}_{2}, \mathrm{CO}, \mathrm{CO}_{2}, \mathrm{NO}_{\mathrm{x}}, \mathrm{SO}_{2}$, and $\mathrm{CH}_{4}$, while the content of dust was measured periodically. The obtained results of flue gases composition are presented in Table 7, while in Figures 6 and 7, exemplary emission plots are shown.

Table 7. * The average composition of exhaust gas on the dirty side (before catalytic ceramic filter) and on the clean side (in the emitter) obtained for fuel mixtures with biochar and coke breeze only.

\begin{tabular}{|c|c|c|c|c|c|c|c|c|}
\hline \multirow{2}{*}{ Parameter } & \multirow{2}{*}{ Unit } & \multirow{2}{*}{$\begin{array}{l}\text { Comparative Sinter, } 100 \% \text { of } \\
\text { Coke Breeze (CB) in the Fuel }\end{array}$} & \multicolumn{2}{|c|}{$\begin{array}{l}\text { Biochar from Residual } \\
\text { Pelletized Sawdust (SDP) }\end{array}$} & \multicolumn{2}{|c|}{$\begin{array}{l}\text { Biochar from Residual } \\
\text { Wood Chips (WdC) }\end{array}$} & \multicolumn{2}{|c|}{$\begin{array}{c}\text { Biochar from Sunflower } \\
\text { Husks (SH) }\end{array}$} \\
\hline & & & Low Share & High Share & Low Share & High Share & Low Share & High Share \\
\hline \multicolumn{9}{|c|}{ Exhaust gas before catalytic ceramic filter (dirty side) } \\
\hline $\mathrm{O}_{2}$ & vol. $\%$ & 13.5 & 13.1 & 12.9 & 13.9 & 13.7 & 12.3 & 12.3 \\
\hline $\mathrm{CO}_{2}$ & vol. $\%$ & 8.24 & 8.54 & 8.65 & 8.48 & 8.49 & 9.14 & 9.31 \\
\hline $\mathrm{CO}$ & vol. $\%$ & 0.96 & 1.10 & 1.20 & 1.21 & 1.32 & 1.16 & 1.24 \\
\hline $\mathrm{CH}_{4}$ & ppm & 19 & 18 & 17 & 29 & 41 & 25 & 45 \\
\hline $\mathrm{SO}_{2}$ & ppm & 134 & 103 & 64 & 89 & 72 & 47 & 46 \\
\hline $\mathrm{NO}_{\mathrm{x}}$ & ppm & 216 & 206 & 190 & 227 & 218 & 259 & 273 \\
\hline Dust & $\mathrm{mg} / \mathrm{Nm}^{3}$ & 222 & 295 & 342 & 279 & 288 & 265 & 363 \\
\hline \multicolumn{9}{|c|}{ Exhaust gas after catalytic ceramic filter (clean side) } \\
\hline $\mathrm{O}_{2}$ & vol. $\%$ & 17.9 & 17.8 & 17.7 & 17.7 & 17.7 & 17.7 & 17.7 \\
\hline $\mathrm{CO}_{2}$ & vol. $\%$ & 4.20 & 4.58 & 4.30 & 4.08 & 4.03 & 4.21 & 4.14 \\
\hline $\mathrm{CO}$ & vol. $\%$ & 0.52 & 0.61 & 0.62 & 0.64 & 0.68 & 0.57 & 0.58 \\
\hline $\mathrm{CH}_{4}$ & ppm & 13 & 13 & 17 & 9 & 23 & 17 & 22 \\
\hline $\mathrm{SO}_{2}$ & ppm & $<1.0$ & $<1.0$ & $<1.0$ & $<1.0$ & $<1.0$ & $<1.0$ & $<1.0$ \\
\hline $\mathrm{NO}_{\mathrm{x}}$ & ppm & 116 & 124 & 102 & 113 & 108 & 131 & 128 \\
\hline Dust & $\mathrm{mg} / \mathrm{Nm}^{3}$ & $<1.0$ & $<1.0$ & $<1.0$ & $<1.0$ & $<1.0$ & $<1.0$ & $<1.0$ \\
\hline
\end{tabular}

${ }^{*}$ For detail results please refer to Table A2 in the Appendix A. 


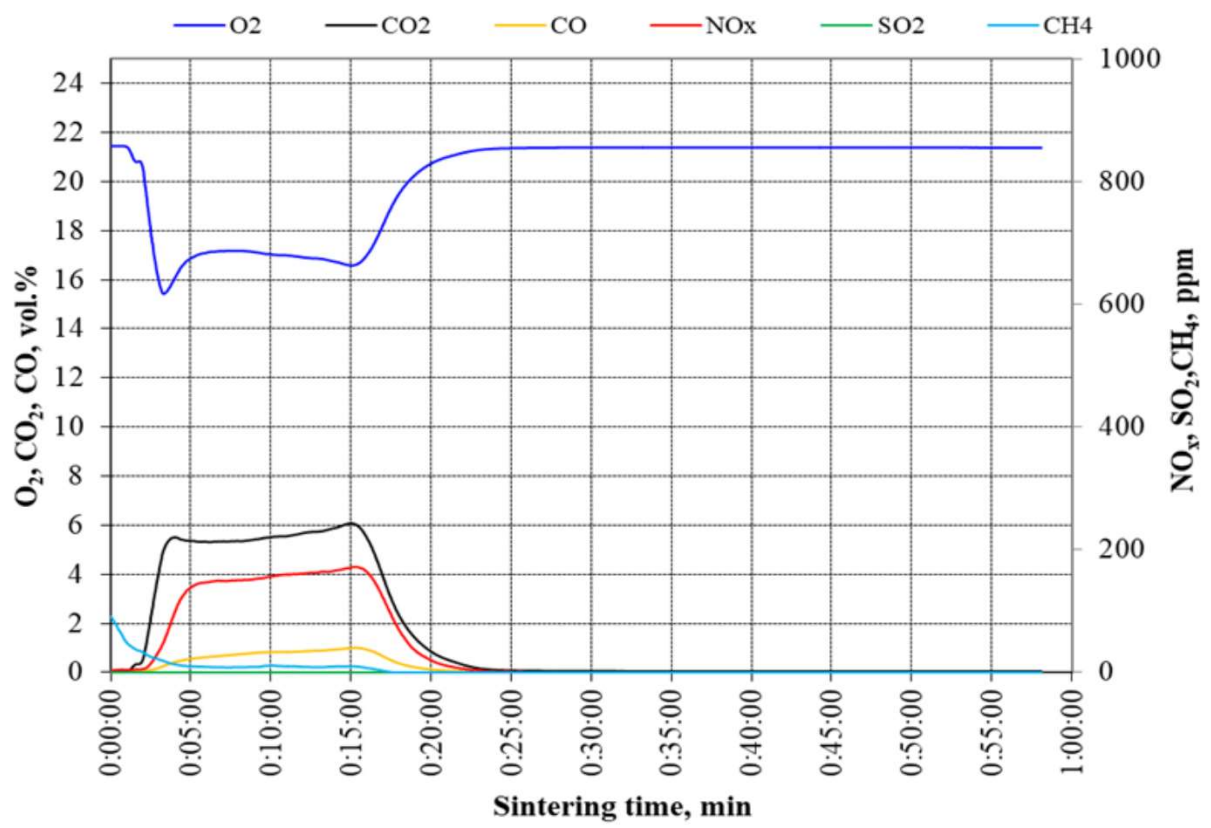

Figure 6. An exemplary composition of exhaust gas on the clean side during sintering with fuel mixtures with biochar.

The measurements of exhaust gas composition allowed us to observe that the use of biochars in the fuel stream resulted in the slight increase of $\mathrm{CO}_{2}$ and $\mathrm{NO}_{\mathrm{x}}$ content $\left(\mathrm{CO}_{2}\right.$ 8.48-9.31 vol.\%; $\mathrm{NO}_{\mathrm{x}} 218-273 \mathrm{ppm}$ ) in comparison with the exhaust gas generated during sintering with fuel composed only of $\mathrm{CB}\left(\mathrm{CO}_{2} 8.24 \mathrm{vol} \%\right.$; $\left.\mathrm{NO}_{x} 216 \mathrm{ppm}\right)$. The exception was the content of $\mathrm{NO}_{\mathrm{x}}$ in exhaust gas formed during the process with the use of SDP biochar, for which the measured concentrations were $190 \mathrm{ppm}$ (high share) and $206 \mathrm{ppm}$ (low share). The amount of CO determined during tests with biochars (1.10-1.32 vol.\%) was also slightly higher than one for tests with CB only (0.96 vol.\%), which could result from the incomplete combustion of biochars during the process. The elevated content of methane (17-45 ppm) noted for fuel mixtures with regard to conventional single component fuel (19 ppm) was probably related to the higher content of volatile matter observed for biochars. On the other hand, lower emissions of $\mathrm{SO}_{2}$ (46-103 ppm) in comparison with $\mathrm{CB}$ (134 ppm) were obtained, which was the result of the lower content of sulfur in pyrolyzed residual biomasses. The periodical measurements of dust content in exhaust gas generated during the sintering process with biomass indicated an increased value of the parameter (265-342 $\left.\mathrm{mg} / \mathrm{Nm}^{3}\right)$ in comparison with standard CB fuel $\left(222 \mathrm{mg} / \mathrm{Nm}^{3}\right)$. In reference to literature data, it was reported that the partial substitution of coke breeze with charcoal resulted in higher concentration of $\mathrm{CO}_{\mathrm{x}}$ and lower concentration of $\mathrm{SO}_{\mathrm{x}}$ and $\mathrm{NO}_{\mathrm{x}}$ in the exhaust gas. The higher concentration of $\mathrm{CO}$ and $\mathrm{CO}_{2}$ was attributed to the higher charcoal addition compared to coke breeze to achieve the return fine balance and sinter quality. The lower concentration of $\mathrm{SO}_{\mathrm{x}}$ and $\mathrm{NO}_{\mathrm{x}}$ was attributed to the lower content of $\mathrm{S}$ and $\mathrm{N}$ in charcoal compared to that of CB [37]. Hence, as in the case of sinter quality, the effect of biochar on emission depends strongly on the biochar quality and process conditions. Additionally, according to [38,39], the use of biochar in the sintering could not be directly followed by a reduction in the greenhouse gas emissions, but the net $\mathrm{CO}_{2}$ emission balance could be reduced by $5-15 \%$, mainly because of the biomass carbon neutrality. 


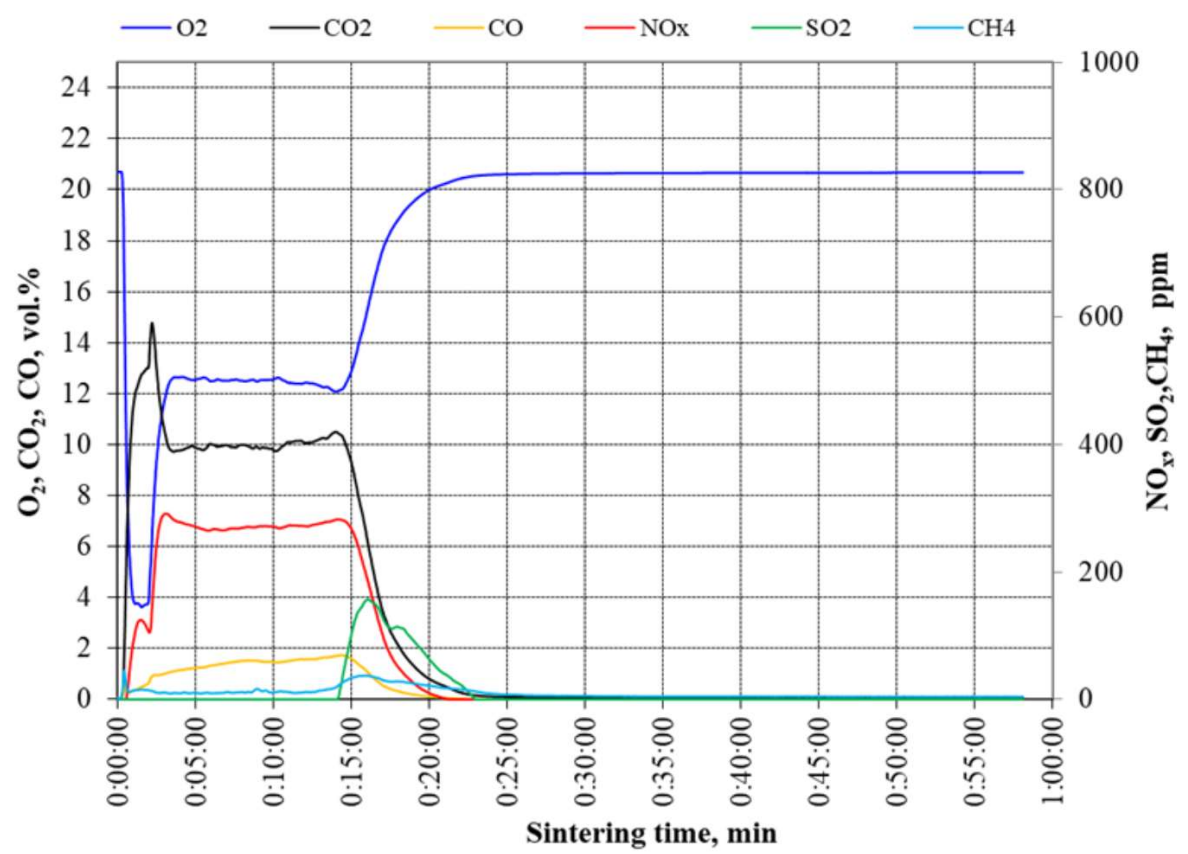

Figure 7. An exemplary composition of exhaust gas on the dirty side during sintering with fuel mixtures with biochar.

The application of catalytic ceramic filter in the semi-industrial-scale iron ores sintering process enabled the significant reduction of pollutants emitted to the atmosphere. It was found that the additional use of hydrated lime sorbent (HLS) allowed for complete sorption of sulfur compounds present in the exhaust gas, as at any stage of emission measurements their concentration was below the detection limit ( $<1.0 \mathrm{ppm}$ (Figure 6)). On the other hand, the presence of $\mathrm{SO}_{2}$ was noted in exhaust gas before the catalytic ceramic filter, which is shown in Figure 7 (green line). The applied HLS was probably also responsible for the decrease of $\mathrm{CO}_{2}$, as the amount of the compound in the gas decreased from $8.24-9.31$ vol.\% to $4.03-4.58$ vol.\%. It was a very desired feature, considering emission limitations of the sintering process. Another advantageous effect was the reduction of $\mathrm{NO}_{\mathrm{x}}$ content by $40-53 \%$, which was obtained due to the presence of the catalyst placed on the ceramic surface of the filter. The content of $\mathrm{CO}$ and $\mathrm{CH}_{4}$ was also significantly decreased (to $0.57-0.68$ vol.\% and to 9-32 ppm, respectively). Thus, it was concluded that the applied catalytic ceramic filter enabled integrated elimination of pollutants by their transformation to $\mathrm{CO}_{2}, \mathrm{~N}_{2}$, and $\mathrm{H}_{2} \mathrm{O}$. Simultaneously, it allowed for very efficient dedusting of the cleaned gas, as the final concentration of dust was always below $1.0 \mathrm{mg} / \mathrm{Nm}^{3}$ (limit of detection), regardless of the fuel composition and process configuration, which corresponded with up to $99.7 \%$ of dedusting efficiency.

As iron ores sintering is the main source of emission of dibenzodioxins/dibenzofurans in integrated steel plants $[27,40]$, the samples of dusts from the catalytic ceramic filter were collected and analyzed with regard to dioxins and furans (PCDD/PCDF) content, as well as to polyaromatic hydrocarbons (PAHs). The dust form during process with $\mathrm{CB}$ fuel was also analyzed. Each time, $85 \mathrm{~g}$ of the sample taken for testing was analyzed. The results of the analysis are presented in Table 8. For comparative purposes, samples of HLS were also analyzed with regard to the content of these specific pollutants [41]. 
Table 8. The content of polyaromatic hydrocarbons (PAHs), dioxins and furans in HLS, and dust collected from the catalytic ceramic filter after the sintering process with coke breeze and mixed fuels.

\begin{tabular}{|c|c|c|c|c|c|}
\hline \multirow[b]{2}{*}{ Component/Congener. } & \multirow[b]{2}{*}{ HLS } & \multirow[b]{2}{*}{ Coke Breeze (CB) } & \multicolumn{3}{|c|}{ Biochar } \\
\hline & & & $\begin{array}{l}\text { Residual Pelletized } \\
\text { Sawdust (SDP) }\end{array}$ & $\begin{array}{l}\text { Residual Wood } \\
\text { Chips (WdC) }\end{array}$ & $\begin{array}{c}\text { Sunflower Husks } \\
\text { (SH) }\end{array}$ \\
\hline \multirow[t]{2}{*}{ PAHs, mg/Sample } & 0.019 & 1.6 & 2.5 & 5.7 & 6.3 \\
\hline & \multicolumn{5}{|c|}{ PCDD and PCDF (dioxins and furans), ng/sample } \\
\hline 2378-TCDD & $<0.0021$ & 0.46 & 0.26 & 0.62 & 0.540 \\
\hline 12378-PeCDD & $<0.0036$ & 1.3 & 0.41 & 1.4 & 1.2 \\
\hline 123478-HxCDD & $<0.006$ & 0.56 & 0.6 & 1.0 & 1.6 \\
\hline 123678-HxCDD & $<0.006$ & 0.92 & 0.44 & 1.1 & 1.4 \\
\hline 123789-HxCDD & $<0.006$ & 0.69 & 0.52 & 1.4 & 1.8 \\
\hline 1234678-HpCDD & $<0.0072$ & 4.6 & 5.20 & 5.1 & 8.8 \\
\hline OCDD & $<0.0092$ & 5.9 & 5.6 & 9.8 & 12.0 \\
\hline 2378-TCDF & $<0.0022$ & 15.0 & 15.0 & 21.0 & 40.0 \\
\hline 12378-PeCDF & $<0.0034$ & 20.0 & 14.0 & 15.0 & 24.0 \\
\hline 23478-PeCDF & $<0.0034$ & 18.0 & 15.0 & 20.0 & 30.0 \\
\hline 123478-HxCDF & $<0.0058$ & 13.0 & 11.0 & 17.0 & 22.0 \\
\hline 123678-HxCDF & $<0.0058$ & 14.0 & 10.0 & 16.0 & 27.0 \\
\hline 123789-HxCDF & $<0.0058$ & 0.006 & 1.2 & 0.9 & 3.7 \\
\hline 234678-HxCDF & $<0.0058$ & 11.0 & 8.3 & 10.0 & 20.0 \\
\hline 1234678-HpCDF & $<0.0075$ & 27.0 & 16.0 & 25.0 & 39.0 \\
\hline 1234789-HрCDF & $<0.0075$ & 4.8 & 2.2 & 3.5 & 5.3 \\
\hline OCDF & $<0.012$ & 18.0 & 11.0 & 18.0 & 26.0 \\
\hline Sum & $<\mathrm{LOD}$ & 155.2 & 116.7 & 166.8 & 264.3 \\
\hline Toxic Equivalent TEQ & 0.01 & 17 & 14 & 19 & 29 \\
\hline
\end{tabular}

Hydrated lime sorbent (HLS) injected to the exhaust gas stream contained trace amounts of PAHs $(0.019 \mathrm{mg} / \mathrm{sample})$ and did not contain PCDD/F. For the use of fuel composed of only CB, the content of PAHs was at the level of $1.6 \mathrm{mg} / \mathrm{sample}$, while the concentration of dioxins and furans was $155.2 \mathrm{ng} /$ sample. The amount of PAHs noted for biochars containing fuel was 1.5-3.9 times higher, which was caused by the significantly higher content of volatile matter.

The highest content of PCDD/F (by up to 70\% with regard to other tested biochars and $(\mathrm{B})$, equal to $264.3 \mathrm{ng} /$ sample and accompanied with the highest toxic equivalent $\mathrm{TEQ}=29$, was noted in the biochar derived from SH. The elevated content of the pollutants (ca. $8 \%$ higher with regard to $\mathrm{CB}$ ) was also noted for residual $\mathrm{WdC}$ and reached $166.8 \mathrm{ng} /$ sample. The lowest concentration of PCDD/F, $116.7 \mathrm{~nm} /$ sample $(25 \%$ lower than CB), was measured for biochar from SDP. Hence, considering amounts of PAHs and $\mathrm{PCDD} / \mathrm{F}$ formed during the process, and appearing in the process gas, it was concluded that biochars from residual WdC or SDP could be efficiently used as substitutional fuel for iron ores sintering processes. Moreover, one must notice that the gas cleaning system involved in the research, comprising of catalytic ceramic filter and hydrated lime sorbent injection, enabled a $90 \%$ reduction of PAHs concentration and $\min .95 \%$ reduction of PCDD/F [18], and the final quality of exhaust gas corresponded to emission requirements established in dedicated legal acts.

\section{Conclusions}

The results obtained during the discussed research allow us to conclude that:

1. The application of pyrolysis to processing of residual biomass enables obtaining of useable fuel for iron ores sintering processes, which can substitute the conventional fuel, i.e., coke breeze. Such an action may lead to a decrease in environmental impacts of the metallurgical industry due to the decrease of emission of GHGs to the atmosphere.

2. The improvement of environmental effect in the form of GHGs emission limitation in the proposed solution results from the fact that the emission, which results from the combustion of volatile components released during pyrolysis (the energy source 
of the process), is regarded as the emission from renewable sources, and the same approach is stated for chars derived from residual biomass.

3. Among biochars produced and tested within the discussed research, the best grain size was obtained for pelletized sawdust, which was especially important considering sintering mixture permeability.

4. The application of biochars in the sintering process resulted in the decrease of $\mathrm{FeO}$ content in the produced sinter. This was a beneficial feature, as the sinter of lower $\mathrm{FeO}$ content was characterized by better reducibility, and thus its reduction to metallic iron in the blast furnace process consumed less coke.

5. The sinter produced with the use of mixed fuels comprising of biochars and coke breeze was characterized by better strength ISO T and abrasion ISO A, as well as with better RI and RDI indicators than the sinter produced with the use of coke breeze only. Hence, the involvement of biochars in the sintering process may improve mechanical and chemical parameters of the final product.

6. The content of carbon in biochars was diversified, while the content of sulfur was always lower than in the case of coke breeze. All biochars revealed elevated potassium content, which was not preferable with regard to possible issues in dedusting, and the impact of their presence was checked during the research.

7. Biochars were characterized by high content of volatile organic matter, and this resulted in more severe formation of hydrocarbons during the sintering process with mixed fuels (coke breeze and biochars).

8. The application of the catalytic ceramic filter and hydrated lime sorbent injection for cleaning of exhaust gas formed during semi-industrial-scale sintering tests allowed for up to $53 \%$ reduction of $\mathrm{NO}_{\mathrm{x}}$ and complete elimination of $\mathrm{SO}_{2}$ present in raw exhaust gases.

9. In the presence of biochars in the sintering fuel, the amount of PAHs present in the raw process gas was higher than in the case of the fuel comprising only coke breeze, and elevated PCDD/F (in the case of this research, however, it was higher only for sawdust-derived char) was noticed. Nevertheless, the proper gas cleaning system (such as the one used in the research composed of catalytic filter and hydrated lime sorbent injection) allows the final concentration of contaminants in the cleaned exhaust gas to be below permissible values stated in environmental emission standards.

Author Contributions: Conceptualization, M.N., J.S. and S.S.; data curation, M.N. and J.S.; investigation, M.N. and J.S.; project administration, A.K.-M.; supervision, S.S.; validation, S.S. and A.K.-M.; writing—original draft, M.N. and J.S.; writing—review and editing, S.S. and A.K.-M. All authors have read and agreed to the published version of the manuscript.

Funding: The work performed under project "The assessment of the use of biomass derived chars as substitute of part of solid fuel in iron ores sintering process". Łukasiewicz-IMŻ report no: S01021/BS/2020. Funding Institution: Polish Ministry of Science and Higher Education. Gliwice, 2020.

Institutional Review Board Statement: Not applicable.

Informed Consent Statement: Not applicable.

Data Availability Statement: Not applicable.

Conflicts of Interest: The authors declare no conflict of interest. 


\section{Appendix A}

Table A1. Detail results of the laboratory sintering tests with low and high share of biochar in fuel.

\begin{tabular}{|c|c|c|c|c|c|c|c|c|c|c|c|c|c|c|c|c|}
\hline & \multirow{3}{*}{ Parameter } & \multirow{3}{*}{ Unit } & \multicolumn{2}{|c|}{$\begin{array}{l}\text { Comparative Sinter, } \\
100 \% \text { of Coke } \\
\text { Breeze in the Fuel }\end{array}$} & \multicolumn{4}{|c|}{$\begin{array}{l}\text { Biochar from Residual Pelletized Sawdust } \\
\text { (SDP) }\end{array}$} & \multicolumn{4}{|c|}{ Biochar from Residual Wood Chips (WdC) } & \multicolumn{4}{|c|}{ Biochar from Sunflower Husks (SH) } \\
\hline & & & \multirow[b]{2}{*}{ Aver. } & \multirow[b]{2}{*}{$\begin{array}{l}\text { Stand. } \\
\text { Dev. }\end{array}$} & \multicolumn{2}{|c|}{ LOW SHARE } & \multicolumn{2}{|c|}{ High Share } & \multicolumn{2}{|c|}{ Low Share } & \multicolumn{2}{|c|}{ High Share } & \multicolumn{2}{|c|}{ Low Share } & \multicolumn{2}{|c|}{ High Share } \\
\hline & & & & & Aver. & $\begin{array}{l}\text { Stand. } \\
\text { Dev. }\end{array}$ & Aver. & $\begin{array}{l}\text { Stand. } \\
\text { Dev. }\end{array}$ & Aver. & $\begin{array}{l}\text { Stand. } \\
\text { Dev. }\end{array}$ & Aver. & $\begin{array}{l}\text { Stand. } \\
\text { Dev. }\end{array}$ & Aver. & $\begin{array}{l}\text { Stand. } \\
\text { Dev. }\end{array}$ & Aver. & $\begin{array}{l}\text { Stand } \\
\text { Dev. }\end{array}$ \\
\hline \multirow{5}{*}{ 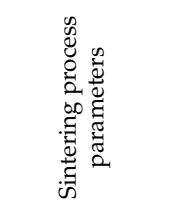 } & \multirow{5}{*}{$\begin{array}{c}\text { Sintering time } \\
\text { Production efficiency } \\
\text { Unit consumption of coke } \\
\text { breeze } \\
\text { Unit consumption of a } \\
\text { biochar } \\
\text { Total fuel consumption }\end{array}$} & $\min$ & 21.43 & 0.49 & 19.85 & 0.70 & 19.54 & 0.56 & 20.58 & 0.26 & 20.71 & 0.79 & 21.53 & 0.60 & 22.77 & 0.09 \\
\hline & & $\mathrm{Mg} / \mathrm{m}^{2} / 24 \mathrm{~h}$ & 37.73 & 0.36 & 39.62 & 1.03 & 39.86 & 0.66 & 38.66 & 0.65 & 37.65 & 1.21 & 36.51 & 0.84 & 34.2 & 0.65 \\
\hline & & $\mathrm{kg} / \mathrm{Mg}$ of sinter & 57.8 & 0.79 & 52.4 & 1.25 & 46.4 & 0.67 & 50.6 & 0.29 & 46.9 & 1.02 & 51.3 & 0.25 & 46 & 0.68 \\
\hline & & $\mathrm{kg} / \mathrm{Mg}$ of sinter & 0 & 0.00 & 6.2 & 0.15 & 12.3 & 0.18 & 5.9 & 0.03 & 12.3 & 0.27 & 6.9 & 0.03 & 14 & 0.21 \\
\hline & & $\mathrm{kg} / \mathrm{Mg}$ of sinter & 57.83 & 0.79 & 58.6 & 1.39 & 58.7 & 0.85 & 56.53 & 0.32 & 59.16 & 1.29 & 58.2 & 0.28 & 59.99 & 0.89 \\
\hline \multirow{12}{*}{ 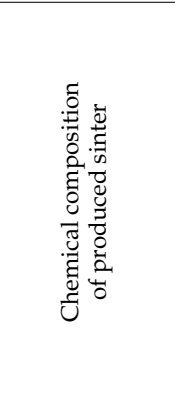 } & $\mathrm{Fe}$ & wt. $\%$ & 54.03 & 0.11 & 54.1 & 0.07 & 54.35 & 0.17 & 54.58 & 0.30 & 54.4 & 0.16 & 54.43 & 0.18 & 54.21 & 0.64 \\
\hline & $\mathrm{FeO}$ & wt. $\%$ & 9.3 & 0.00 & 7.13 & 0.53 & 6.32 & 0.41 & 6.3 & 0.71 & 6.4 & 0.14 & 6.18 & 1.01 & 5.46 & 0.21 \\
\hline & $\mathrm{SiO}_{2}$ & wt. $\%$ & 10.32 & 0.35 & 10.28 & 0.22 & 10.25 & 0.09 & 9.73 & 1.24 & 8.95 & 0.13 & 9.75 & 0.38 & 8.61 & 0.40 \\
\hline & $\mathrm{CaO}$ & wt. $\%$ & 11.21 & 0.21 & 11.22 & 0.13 & 10.92 & 0.13 & 11.15 & 0.55 & 11.43 & 0.01 & 11.09 & 0.37 & 11.37 & 0.25 \\
\hline & $\mathrm{Al}_{2} \mathrm{O}_{3}$ & wt. $\%$ & 0.60 & 0.01 & 0.59 & 0.00 & 0.56 & 0.04 & 0.57 & 0.01 & 0.58 & 0.00 & 0.58 & 0.00 & 0.57 & 0.01 \\
\hline & $\mathrm{TiO}_{2}$ & wt. $\%$ & 0.019 & 0.001 & 0.017 & 0.000 & 0.019 & 0.001 & 0.019 & 0.003 & 0.019 & 0.000 & 0.018 & 0.002 & 0.019 & 0.001 \\
\hline & $\mathrm{MgO}$ & wt. $\%$ & 1.32 & 0.01 & 1.33 & 0.04 & 1.31 & 0.09 & 1.24 & 0.08 & 1.22 & 0.03 & 1.26 & 0.08 & 1.3 & 0.04 \\
\hline & $\mathrm{P}$ & wt. $\%$ & 0.023 & 0.002 & 0.024 & 0.003 & 0.021 & 0.001 & 0.024 & 0.001 & 0.024 & 0.001 & 0.023 & 0.001 & 0.026 & 0.001 \\
\hline & $\mathrm{Mn}$ & wt. $\%$ & 0.032 & 0.000 & 0.033 & 0.000 & 0.016 & 0.018 & 0.029 & 0.001 & 0.165 & 0.191 & 0.03 & 0.003 & 0.029 & 0.000 \\
\hline & $\mathrm{S}$ & wt. $\%$ & 0.019 & 0.003 & 0.023 & 0.001 & 0.024 & 0.000 & 0.035 & 0.006 & 0.034 & 0.001 & 0.031 & 0.001 & 0.03 & 0.000 \\
\hline & $\mathrm{K}_{2} \mathrm{O}$ & wt. $\%$ & 0.023 & 0.001 & 0.025 & 0.003 & 0.023 & 0.001 & 0.029 & 0.001 & 0.029 & 0.001 & 0.033 & 0.005 & 0.044 & 0.005 \\
\hline & $\mathrm{Cl}$ & wt. $\%$ & 0.007 & 0.002 & 0.005 & 0.001 & 0.005 & 0.001 & 0.01 & 0.001 & 0.009 & 0.000 & 0.006 & 0.001 & 0.005 & 0.000 \\
\hline \multirow{6}{*}{$\begin{array}{l}\text { Grain size } \\
\text { analysis of } \\
\text { produced } \\
\text { sinter }\end{array}$} & $>40 \mathrm{~mm}$ & wt. $\%$ & 13.54 & 2.38 & 12.55 & 1.68 & 12.18 & 0.70 & 11.07 & 1.10 & 11.47 & 1.38 & 12.61 & 1.58 & 12.44 & 0.90 \\
\hline & $>25 \mathrm{~mm}$ & wt. $\%$ & 20.47 & 0.96 & 22.8 & 0.79 & 22.55 & 1.38 & 25.11 & 0.74 & 25.1 & 0.92 & 24.86 & 0.07 & 26.05 & 1.13 \\
\hline & $>15 \mathrm{~mm}$ & wt. $\%$ & 21.42 & 0.99 & 21.94 & 0.61 & 21.13 & 0.85 & 22.31 & 1.12 & 22.3 & 1.32 & 21.35 & 0.52 & 20.98 & 1.30 \\
\hline & $>10 \mathrm{~mm}$ & wt. $\%$ & 17.97 & 1.43 & 16.59 & 0.41 & 17.31 & 0.80 & 16.56 & 1.36 & 17.18 & 0.67 & 16.96 & 0.49 & 16.31 & 0.51 \\
\hline & $>5 \mathrm{~mm}$ & wt. $\%$ & 26.6 & 1.14 & 26.12 & 0.45 & 26.84 & 0.66 & 24.94 & 0.24 & 23.94 & 0.42 & 24.21 & 0.67 & 24.23 & 1.02 \\
\hline & Median & $\mathrm{mm}$ & 17.06 & 0.80 & 17.78 & 0.33 & 17.29 & 0.20 & 18.24 & 0.59 & 18.39 & 0.34 & 18.54 & 0.59 & 18.88 & 0.43 \\
\hline \multirow{2}{*}{ Sinter strength } & Strength ISO T > $6.3 \mathrm{~mm}$ & wt. $\%$ & 68.17 & 0.44 & 69.82 & 0.96 & 70.57 & 0.54 & 70.76 & 0.72 & 69.18 & 0.19 & 70.58 & 0.10 & 69.59 & 0.27 \\
\hline & Abrasion ISO A $<0.5 \mathrm{~mm}$ & wt.\% & 5.8 & 0.35 & 5.59 & 0.07 & 5.57 & 0.09 & 5.61 & 0.03 & 5.56 & 0.14 & 5.69 & 0.18 & 5.66 & 0.09 \\
\hline RDI & $<3.15 \mathrm{~mm}$ & wt. $\%$ & 17.7 & 0.71 & 15.6 & 2.05 & 16.4 & 0.07 & 13.8 & 0.78 & 12.2 & 0.71 & 16.1 & 0.78 & 17.4 & 1.34 \\
\hline RI & $\mathrm{dR} / \mathrm{dt}(\mathrm{O} / \mathrm{Fe}=0.9)$ & $\% / \min$ & 0.96 & 0.06 & 0.98 & 0.07 & 1.09 & 0.02 & 1.13 & 0.16 & 1.17 & 0.15 & 1.12 & 0.08 & 1.14 & 0.05 \\
\hline
\end{tabular}




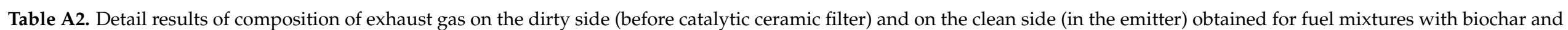
coke breeze only.

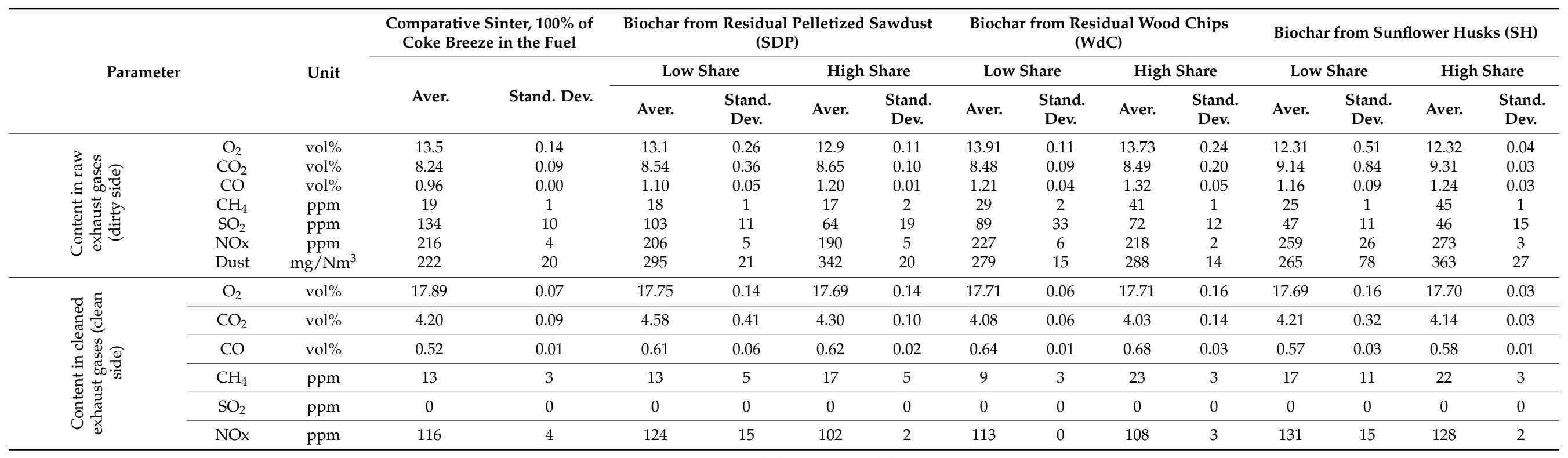




\section{References}

1. Palm, J.; Bocken, N. Achieving the Circular Economy: Exploring the Role of Local Governments, Business and Citizens in an Urban Context. Energies 2021, 14, 875. [CrossRef]

2. EC European Commission-Environment-Circular Economy Strategy. Available online: http://ec.europa.eu/environment/ circular-economy/index_en.htm (accessed on 12 April 2021).

3. Stelmach, S. Pyrolysis of Residues and Wastes as an Element of Circular Economy (Piroliza Odpadów Jako Element Gospodarki o Obiegu Zamkniętym); Monograph; Silesian University of Technology Publishing: Gliwice, Poland, 2019. (In Polish)

4. Ma, S.; Wen, Z.; Chen, J.; Wen, Z. Mode of circular economy in China's iron and steel industry: A case study in Wu'an city. J. Clean. Prod. 2014, 64, 505-512. [CrossRef]

5. Branca, T.A.; Colla, V.; Algermissen, D.; Granbom, H. Reuse and Recycling of By-Products in the Steel Sector: Recent Achievements Paving the Way to Circular Economy and Industrial Symbiosis in Europe. Metals 2020, 10, 345. [CrossRef]

6. Echterhof, T. Review on the use of alternative carbon sources in EAF steelmaking. Metals 2021, 11, 222. [CrossRef]

7. Rejdak, M.; Bigda, R.; Wojtaszek, M. Use of Alternative Raw Materials in Coke-Making: New Insights in the Use of Lignites for Blast Furnace Coke Production. Energies 2020, 13, 2832. [CrossRef]

8. Stanek, W.; Szega, M.; Blacha, L.; Niesler, M.; Gawron, M. Exergo-Ecological assessment of auxiliary fuel injection into blastfurnace. Arch. Metall. Mater. 2015, 60, 711-719. [CrossRef]

9. Alwaeli, M.; Gołaszewski, J.; Niesler, M.; Pizoń, J.; Gołaszewska, M. Recycle option for metallurgical sludge as a partial replacement for natural sand in mortars containing CSA cement to save the environment and natural resources. J. Hazard. Mater. 2020, 398, 123101. [CrossRef] [PubMed]

10. Stecko, J.; Stachura, R.; Niesler, M.; Bernasowski, M.; Klimczyk, A. Utilisation of metallurgical sludge by multi-layer sintering. Ironmak. Steelmak. 2018, 45, 779-786. [CrossRef]

11. Łabaj, J.; Blacha, L.; Smalcerz, A.; Wieczorek, J.; Frohlichova, M.; Findorák, R.; Vadász, P.; Niesler, M. Utilization of waste coal flotation concentrate for copper matte smelting. Eng. Sci. Technol. Int. J. 2021, 24, 996-1004.

12. Zhou, M.; Yu, Z.; Wang, P.; Xie, H.; Wen, Y.; Li, J. Thermodynamic Analysis of Iron Ore Sintering Process Based on Biomass Carbon. Energies 2020, 13, 5988. [CrossRef]

13. Wasielewski, R.; Sobolewski, A. Industrial utilization of spent ion-exchange resin in the coke battery. Coke Chem. 2011, 54, 66-71. [CrossRef]

14. Lu, L.; Ishiyama, O. Iron ore sintering. In Iron Ore Sintering. Mineralogy, Processing and Environmental Sustainability; Elsevier Ltd.: Amsterdam, The Netherlands, 2015; pp. 395-433.

15. Fernández-González, D.; Ruiz-Bustinza, I.; Mochón, J.; González-Gasca, C.; Verdeja, L.F. Iron Ore Sintering: Process. Miner. Process. Extr. Metall. Rev. 2017, 38, 215-227. [CrossRef]

16. Kruzhanov, V.; Arnhold, C. Energy consumption in powder metallurgical manufacturing. Powder Metall. 2012, 55, 14-21. [CrossRef]

17. Jha, G.; Soren, S. Study on applicability of biomass in iron ore sintering process. Renew. Sustain. Energy Rev. 2017, 80, 399-407. [CrossRef]

18. Zhang, X.; Zhong, Q.; Liu, C.; Rao, M.; Peng, Z.; Li, G.; Jiang, T. Partial substitution of anthracite for coke breeze in iron ore sintering. Sci. Rep. 2021, 11, 1540. [CrossRef] [PubMed]

19. Camia, A.; Robert, N.; Jonsson, K.; Pilli, R.; Garcia Condado, S.; Lopez Lozano, R.; Van Der Velde, M.; Ronzon, T.; Gurria Albusac, P.; M'barek, R.; et al. Biomass Production, Supply, Uses and Flows in the European Union: First Results from an Integrated Assessment; EUR 28993 EN; Publications Office of the European Union: Luxembourg, 2018. [CrossRef]

20. Koryś, K.A.; Latawiec, A.E.; Grotkiewicz, K.; Kuboń, M. The Review of Biomass Potential for Agricultural Biogas Production in Poland. Sustainability 2019, 11, 6515. [CrossRef]

21. Vassilev, S.; Vassileva, C.; Vassilev, V.S. Advantages and disadvantages of composition and properties of biomass in comparison with coal: An overview. Fuel 2015, 158, 330-350. [CrossRef]

22. Kawaguchi, T.; Hara, M. Utilization of biomass for iron ore sintering. ISIJ Int. 2013, 53, 1599-1606. [CrossRef]

23. Zandi, M.; Martinez-Pacheco, M.; Fray, T. Biomass for iron ore sintering. Miner. Eng. 2010, 23, 1139-1145. [CrossRef]

24. De Castro, J.A.; de Oliveira, E.M.; de Campos, M.F.; Takano, C.; Yagi, J. Analyzing cleaner alternatives of solid and gaseous fuels for iron ore sintering in compacts machines. J. Clean. Prod. 2018, 198, 654-661. [CrossRef]

25. Uddin, M.N.; Techato, K.; Taweekun, J.; Rahman, M.M.; Rasul, M.G.; Mahlia, T.M.I.; Ashrafur, S.M. An Overview of Recent Developments in Biomass Pyrolysis Technologies. Energies 2018, 11, 3115. [CrossRef]

26. Jahanshahi, S.; Deev, A.; Haque, N.; Lu, L. Recent progress in R\&D on assessment of the use of biomass/designer chars for steel production. In Proceedings of the Innovation of Ironmaking Technologies and Future International Collaboration-to Overcome Energy, Tokyo, Japan, 10-11 November 2014; pp. 123-138.

27. Best Available Techniques (BAT) Reference Document for Iron and Steel Production. 2013. Available online: https://ideas.repec. org/p/ipt/iptwpa/jrc69967.html (accessed on 20 April 2021).

28. Ostrowska-Popielska, P.; Sorek, A. Possibility of the use of biomass in metallurgical processes (Możliwości wykorzystania biomasy w procesach hutniczych). Work. Inst. Ferr. Metall. 2013, 4, 46-52. (In Polish) 
29. Jha, G.; Mehta, K.D.; Soren, S. Partial substitution of coke breeze with biomass and charcoal in metallurgical sintering. Fuel 2020, 278, 1-9. [CrossRef]

30. Mežibrický, R.; Fröhlichová, M.; Mašlejová, A. Phase composition of iron ore sinters produced with biomass as a substitute for the coke fuel. Arch. Metall. Mater. 2015, 60, 2955-2963. [CrossRef]

31. Institute for Chemical Processing of Coal: Testing Plant for Solid Fuels Pyrolysis/Gasification. Available online: http:// www.ichpw.pl/en/wp-content/uploads/sites/2/2015/09/Testing-plant-for-solid-fuelspyrolysis-gasification-1.pdf (accessed on 24 May 2021).

32. Łukasiewicz Research Network-Institute for Ferrous Metallurgy. Line for Semi-Industrial Simulation of Iron Ores And Waste Sintering with Use of Novel System of Exhaust Gas Neutralization (LS). Available online: https://www.imz.pl/en/aktualnosci. php? wid=31\&news=605\&druk=1 (accessed on 24 May 2021).

33. ISO Standard No 3271:2015: Iron Ores for Blast Furnace and Direct Reduction Feedstocks—Determination of the Tumble and Abrasion Indices. Available online: https:/ /www.iso.org/obp/ui/\#iso:std:iso:3271:ed-5:v1:en (accessed on 24 May 2021).

34. Helle, H.; Helle, M.; Saxén, H.; Frank, P. Mathematical optimization of ironmaking with biomass as auxiliary reductant in the blast furnace. ISIJ Int. 2009, 49, 1316-1324. [CrossRef]

35. Fan, X.; Ji, Z.; Gan, M.; Chen, X.; Yin, L.; Jiang, T. Characteristics of Prepared Coke-biochar Composite and Its Influence on Reduction of $\mathrm{NO}_{x}$ Emission in Iron Ore Sintering. ISIJ Int. 2015, 55, 521-527. [CrossRef]

36. Ye, L.; Peng, Z.; Wang, L.; Anzulevivh, W.; Bychkov, I.; Kalganov, D.; Tang, H.; Rao, M.; Li, G.; Jiang, T. Use of Biochar for Sustainable Ferrous Metallurgy. JOM 2019, 71, 3931-3940. [CrossRef]

37. Lu, L.; Adam, M.; Kilburn, M.; Hapugoda, S.; Somerville, M.; Jahanshahi, S.; Mathieson, J.G. Substitution of charcoal for coke breeze in iron ore sintering. ISIJ Int. 2013, 53, 1607-1616. [CrossRef]

38. Mathieson, J.G.; Norgate, T.; Jahanshahi, S.; Somerville, M.A.; Haque, N.; Deev, A.; Ridgeway, P.; Zulli, P. The potential for charcoal to reduce net greenhouse gas emissions from the Australian steel industry. In Proceedings of the 6th International Congress on the Science and Technology of Ironmaking (ICSTI), Rio de Janeiro, Brazil, 14-18 October 2012; Volume 6. [CrossRef]

39. Mousa, E.; Wang, C.; Riesbeck, J.; Larsson, M. Biomass applications in iron and steel industry: An overview of challenges and opportunities. Renew. Sustain. Energy Rev. 2016, 65, 1247-1266. [CrossRef]

40. Grochowalski, A.; Lassen, C.; Holtzer, M.; Sadowski, M.; Hudyma, T. Determination of PCDDs, PCDFs, PCBs and HCB emissions from the metallurgical sector in Poland. Environ. Sci. Pollut. Res. 2007, 14, 326-332. [CrossRef]

41. Niesler, M.; Stecko, J. Demonstrative Technology for Cleaning Flue Gas from DL2 Sinter Belt in ArcelorMittal Poland S.A., Unit in Dabrowa Górnicza, Meeting the Requirements Specified in Best Available Techniques (BAT) for the Production of Iron and Steel (Project No. POIR.01.01.01-00-0782/17); Report No B0 1612; Non-Public Project Report of Institute for Ferrous Metallurgy: Gliwice, Poland, 2019. (In Polish) 